NOTE

\title{
NFL FREE AGENCY RESTRICTIONS UNDER ANTITRUST ATTACK
}

\section{INTRODUCTION}

For the past several years, the players of the National Football League (NFL) have been engaged in a battle with team owners over free agency ${ }^{1}$ and the restrictions that NFL owners attempt to place upon its exercise. ${ }^{2}$

In 1987, the National Football League Players' Association (NFLPA) and several individual players filed an antitrust suit agamst the NFL owners, ${ }^{3}$ claiming that the League's free agency restrictions vio-

1. Free agency is the system that enables professional athletes to change sports teams after their contracts expire. If free agency is unrestricted, a player can negotiate and sign with any team after his contract expires.

Free agency is an important right for professional athletes. Professional sports leagnes conduct drafts in which a single team acquires the rights to contract with a player entering the leagne. If no free agency existed, that player would be rcquired to play with his drafting team throughout his career, barring a trade or release. With free agency, the player may switch teams if the drafting team fails to sign the player initially, or after his contract with the drafting team expires.

A player who switches teams under a free agency system has greatcr control over his career than a player who switches teams through a trade. In a trade, a player does not necessarily choose the team to which he is traded, although a few "stars" have clauses in their contracts specifically granting veto power over a proposed deal.

2. The restrictions on free agency are attempts to prevent players from switching teams. Generally, the restrictions make it more difficult and costly both for owners and players to use the free agency system. Five different methods are or have been used to restrict the use of the free agency system. Eligibility requirements restrict free agency to only those players with a certain amount of leagne experience. Compensation schemes require the team signing a free agent to give the team losing the player something in return. The compensation may or may not be predetermined, and generally involves money, draft choices, and/or players already in the leagne. The players already in the league may come directly from the team signing the free agent or from a league-wide pool of players designated as eligible. Rights of first refusal allow the team with a potential free agent to automatically retain that player if it inatches all other interested teams' offers. Salary caps limit the total amount a team inay expend on salaries. In theory, teams cannot sign free agents who push them over this cap. The reserve rule eliminates free agency by giving the team originally signing a player the right to resign that player in perpetuity. With regard to all the restraints except the reserve rule, players may be subject to different restrictions, based on their ability, salary, or experience level.

3. Powell v. NFL, Civ. No. 4-87-917 (D. Miun. filed Oct. 15, 1987). 
lated Section 1 of the Sherman Anti-Trust Act. ${ }^{4}$ Since that claim was filed, the NFL and the NFLPA have been engaged in prolonged litigation over whether the NFL free agency restrictions can be challenged under the antitrust laws. ${ }^{5}$

This Note uses a statistical model to examine whether the NFL's free agency restrictions violate Section 1 of the Sherman Act. The statistical model describes the economic structure of the NFL and other sports leagues, and quantifies the impact that individual players have on the revenues of an NFL team. The model thus enables a full assessment of the effect that free agency restrictions have on the three factors-the labor market, the product, and the consumer-relevant to Section 1 analysis. ${ }^{6}$

\section{A. The NFL Free Agency Dispute}

The current NFL free agency dispute began in the 1987-1988 season when the NFLPA went on strike primarily because of the disagreement between players and owners over free agency restrictions. ${ }^{7}$ When the strike proved ineffective, the players resumed play under a modified free agency system. ${ }^{8}$ Immediately after the strike ended, the NFLPA filed an

4. Section 1 of the Sherman Act provides that "[e]very contract, combination in the form of trust or otherwise, or conspiracy, in restraint of trade or commerce among the several states or with foreign nations, is declared illegal." 15 U.S.C. § 1 (1988).

5. The dispute focuses on the application of the non-statutory labor exemption. If the exemption applies, it immunizes the frec agency restrictions from the Sherman Act.

There has yet to be a ruling on the merits of the antitrust claim in the Powell dispute. Although recent rulings indicate that the frec agency restrictions will be immune from antitrust attack in this particular sinit, it is likely that NFL free agency restrictions will be subjeet to antitrust scrutiny at soine point in the near future.

6. The statistical model was developed in my senior thesis at Princeton University, entitled The Determinants of Free Agency Effectiveness in the Sports Industries [hereinafter Thesis]. A copy is on file at Primceton University and in the Duke Law Journal offices.

7. Players contended that the restrictions decreased their mobility and reduced their salaries. See NFL Labor Issues, USA Today, Sept. 17, 1987, at 3C (describing labor issues leading to the 1987 NFL strike). Prior to the 1987 strike, no player who was subject to the League's free agency restrictions switched teams via the free agent system. In 1985, the average NFL player's salary was $\$ 190,000$. P. Staudohar, The Sports Industry aNd Collective Bargaining 73 (1986). By comparison, the average salary that year in the NBA was $\$ 395,000$, id. at 100 , and in Major League Baseball was \$371,157. Id. at 29.

It slould be noted that free agency has not always been the focal point of NFL labor disputes. See R. Berry, Labor Relations in Professional Sports 134 (1986) (1982 NFL strike and collective bargaining agreement did not focus on frec agency).

8. The owners unilaterally imposed a inodified frec agency system that upheld prior restrictions but applied them only to certain players. See Forbes, Controversial New Plan Goes into Effect Today, USA Today, Feb. 1, 1989, at 3, col. 2 (players gradually returned); see also infra notes 21 \& 52 and accompanying text. 
antitrust suit against the owners, claiming that the league's free agency restrictions violated Section 1 of the Sherman Act. ${ }^{9}$

Since then, litigation lias focused on whether the free agency restrictions are subject to antitrust scrutiny at all or whether they are immunized froin free agency restrictions. If players and owners agreed to a condition of employment in a previous contract, then a non-statutory labor exemption will immunize the condition from antitrust scrutiny. ${ }^{10}$ The NFLPA and the NFL owners agreed to the free agency restrictions in their 1982 collective bargaining agreement, ${ }^{11}$ which expired in 1987. But in 1988, the owners and players reached an impasse in negotiations. ${ }^{12}$ In the first Powell v. NFL case, ${ }^{13}$ the two sides disagreed about whether the labor exemption was terminated under these conditions. The Eighth Circuit reversed the district court, ruling that the labor exemption did not terminate when the sides reached an impasse, but rather that it "protect[ed] agreements conceived in an ongoing collective bargaining relationship." 14 Although the Eight Circuit's decision has been hotly debated by several commentators, ${ }^{15}$ the Supreme Court's recent denial of the NFL's petition for certiorari ${ }^{16}$ effectively immunized the free agency restrictions from antitrust attack.

Despite this ruling, three factors indicate that NFL free agency restrictions eventually will be scrutinized under the antitrust laws. First, the NFL players are in the process of decertifying the union. The players contend that the labor exemption exists only in bargaining between a union and its employer. If this is true, then the labor exemption will be inapplicable once decertification is coinplete and any NFL player will be able to challenge the League's free agency restrictions on antitrust grounds. ${ }^{17}$ After decertification, and once an individual player conies

9. Powell v. NFL, Civ. No. 4-87-917 (D. Minn. filed Oct. 15, 1987). For an excellent summary of the substantive and procedural history of the NFL dispute through the Eighth Circuit's ruling, see Roman, Illegal Procedure: The National Football League Player Union's Improper Use of Antitrust Litigation for Purposes of Collective Bargaining, 67 DEN. U.L. REV. 110 (1990).

10. Powell v. NFL, 678 F. Supp. 777 (D. Minn. 1988), rev'd, 888 F.2d 559 (8th Cir. 1989), cert. denied, 111 S. Ct. 711 (1991). The Eighth Circuit had previously pointed out that the exemption applies "where the [challenged] restraint ... primarily affects only the parties to the collective bargaining relatiouship, [and] ... the agreement concerns a mandatory subject of collective bargaining, [and is] the product of bona fide arm's-length bargaining." Mackey v. NFL, 543 F.2d 606, 614 (8th Cir. 1976).

11. See infra notes $49-51$ and accompanying text.

12. Powell v. NFL, 690 F. Supp. 812,814 (D. Minn. 1988).

13. Powell v. NFL, 678 F. Supp. 777 (D. Minn. 1988).

14. Powell v. NFL, 888 F.2d 559, 568 (8th Cir. 1989).

15. See Lock, The Eighth Circuit Sacks the National Football League Players Association, 67 DEN. U.L. REV. 135 (1990); Roman, supra note 12.

16. Powell v. NFL, 111 S. Ct. 711 (1991).

17. See Roman, supro note 9, at 115-16. 
forth as a test case, courts will scrutinize the free agency restrictions under antitrust laws. ${ }^{18}$

Second, antitrust analysis might be applied to the free agency restrictions that the owners unilaterally imposed on players when the 1987 strike failed. In McNeil v. NFL, ${ }^{19}$ several players alleged that the newlymiposed restrictions violated Section 1 of the Sherman Act. The players reasoned that since the players never agreed to the unilaterally imposed restrictions, the labor exemption did not apply to those restrictions. ${ }^{20}$ The owners claim that the labor exemption immunizes these restrictions froin antitrust scrutimy because, under Powell, the unilateral restrictions were part of an agreeinent conceived in an ongoing collective bargaining relationship. ${ }^{21}$

Finally, even if neither the decertification nor the action against the unilaterally miposed restrictions produces an antitrust ruling, it would appear that at some point the restrictions will no longer be deeined to be "conceived in an ongoing collective bargaining relationship." The Eighth Circuit ruled that an impasse does not terminate the antitrust exeinption, but further stated that manageinent was not forever exempt from antitrust scrutiny once it had entered into a collective bargaining agreeinent. ${ }^{22}$ The court did not indicate when this termination point would be reached; when it does occur, free agency restrictions will be scrutinized under antitrust laws. ${ }^{23}$

\section{B. Purpose of Note}

This Note focuses exclusively on free agency restrictions and the antitrust considerations of Section 1 of the Sherman Act. ${ }^{24}$ Restrictions on free agency may be challenged as either per se violations of this provi-

18. The owners have filed a suit against the NFLPA seeking a declaratory judgment that the NFLPA's decertification is iueffective to terminate the labor exemption recognized by the Eighth Circuit. Five Smiths, Inc. v. NFLPA, Civ. No. 4-90-261 (D. Minn. filed Mar. 30, 1990). The court has yet to issue its ruling.

19. Civ. No. 90-14-02-JNB (D.N.J. filed Apr. 10, 1990).

20. See Roman, supra note 9.

21. Id.

22. Powell, 888 F.2d at 568 .

23. The free agency restrictions in baseball are not subject to antitrust laws because Major Leagne Baseball has an antitrust exemption, which it gained in Federal Baseball Club v. National Leagne, 259 U.S. 200 (1922), and Toolson v. New York Yankees, 346 U.S. 356 (1953). Baseball has kept.its exemption, see Flood v. Kuhn, 407 U.S. 258 (1972), even though courts later denied the exemption to other professional sports. See Radovich v. NFL, 352 U.S. 445 (1957) (football); Umited States v. International Boxing Club, 348 U.S. 236 (1955) (boxing). But see Glassen, Three Strikes and You're Out: An Investigation of Professional Baseball's Antitrust Exemption, 21 AxRoN L. REV. 369 (1988) (argumg that the courts should abandon baseball's antitrust exemption). 24. 15 U.S.C. $\S 1$ (1988). 
sion $^{25}$ or as invalid under the "Rule of Reason."26 Since courts have been reluctant to apply the per se rule to the business practices of sports leagues, ${ }^{27}$ this Note focuses on whether various restraints are valid under the Rule of Reason standard.

The underlying assumption of this Note is that courts have not adequately considered certain economic factors when they evaluated the reasonableness of free agency restrictions. ${ }^{28}$ Although courts often use soine form of economic analysis in decisions concerning free agency restrictions, they inake incorrect economic assumptions about the workings of sports markets. Courts gloss over the differences between sports leagues, assuming that each league works in the saine way and that similar restrictions produce similar results. In fact, the variations among the economic structures of the different sports leagues should have a significant impact on antitrust analysis. This Note einploys a statistical inodel ${ }^{29}$ to examine these variances, to determine the impact an individual player has on actual revenues, and to determine the corresponding effect of free agency on revenues.

Courts have also made the mistake of considering too narrow a range of coinpetitive and anticoinpetitive effects created by free agency restrictions. In sports settings, courts have evaluated frec agency restrictions in light of their effects on competition in the labor market-in other words, the effects of these restrictions on players. ${ }^{30}$ Thus, courts have viewed free agency restrictions, which by their nature impede player

25. Where a restraint is characterized as a per se violation, the court does not inquire into the alleged justification for the restraint; the type of restriction is conclusively presumed to be unreasonable. National Soc'y of Professional Eng'rs v. United States, 435 U.S. 679, 692 (1978); Mackey v. NFL, 543 F.2d 606, 618 (8th Cir. 1976).

26. Under the Rule of Reason test, courts will not conclusively presume that the challenged restraint violates the Sherman Act, but will inquire into the potential justifications for the restraint. Professional Engineers, 435 U.S. at 692; Mackey, 543 F.2d at 620

27. Courts are reluctant to apply the per se test because of their general unfamiliarity with sports practices, and because of the uniqueness of the sports business. See NCAA v. Board of Regents, 468 U.S. 85, 100-101 (1984) (NCAA's broadcasting policies that created horizontal pricefixing and output limitations not examined as a per se violation of the Sherman Act but examined under the rule of reason); Smith v. Pro Football Inc., 593 F.2d 1173, 1179-82 (1978) (policies of the NFL player draft found not to be a group boycott of the type traditionally found per se violative of the Sherman Act, and therefore governed by the rule of reason); Mackey, 543 F.2d at 619 (NFL teams are urique because they act like joint ventures, not as competitors in the traditional seuse); Rosenbaum, The Antitrust Implications of Professional Sports Leagues Revisited: Emerging Trends in the Modern Era, 41 U. MIAMI L. REV. 729, 740 n.42 (1987) ("The rule of reason appears to have won out as the proper test in evaluating the section 1 miphications of sports league conduct.").

28. Disputes in several professional sports leagues over whether free agency restrictions violate Section 1 of the Sherman Act have previously been decided in the courts. Flood v. Kuhn, 407 U.S. 258 (1972); Mackey, 543 F.2d at 606; Robertson v. NBA, 389 F. Supp. 867 (S.D.N.Y. 1975).

29. See supra note 6.

30. See Mackey, 543 F.2d at 534; Robertson, 389 F. Supp. at 882-83. 
movement and depress player salaries, as anticompetitive. What these courts have failed to consider is the competitive effects that free agency restrictions have on the product in question, NFL football, and on consumer welfare. Although it could be argued that consumer welfare should be the ouly factor considered in antitrust analysis, this Note takes the position that courts should consider all of the above factors-the labor market, the product, and consumer welfare-when determining whether a Section 1 violation has occurred. Consideration of all these competitive effects has a significant impact on whether free agency restrictions are reasonable under the Rule of Reason standard.

After analyzimg these factors, the Note concludes that certain restrictions on free agency in the NFL are not only procompetitive in overall effect, but may benefit players, owners, and consumers as well. Such restrictions are thus reasonable and do not violate the antitrust laws. By comparison, identical restrictions imposed by other sports leagues do not support the same conclusion.

Part II of the Note describes the development of free agency in the NFL, with a comparison of its development in other sports, to illustrate the striking differences among sports leagues. Part III sets forth the apphicable antitrust laws and discusses which factors inust be considered in evaluating the effects that free agency restrictions have on competition. The Note suggests that courts should focus not ouly on coinpetitive effects on the labor market, but also on the product market and on consumer welfare. Part IV presents a statistical model to determine the economic realities of different sports leagues. Finally, Parts V and VI evaluate the economic assumptions inade by the courts, concluding that they have erred in assuming that all sports leagues are the same, and propose a method of analysis for resolving the current conflict.

\section{Development of The Free Agency System}

\section{A. The National Football League ${ }^{31}$}

1. The Reserve Rule. The NFL has employed several types of free agency systems throughout its history. The NFL imitially utilized a system known as the reserve rule, which bound a player to one team indefinitely. ${ }^{32}$ Under the reserve rule, every players' contract contained a clause providing that a club had the right to renew the player's contract for another term of one year on the same terms as the previous contract,

31. See Roman, supra note 9, at 249 (providing a history of free agency restrictions in the NFL).

32. P. STAudohaR, supra note 7 , at 78. 
subject to certain qualifications regarding salaries. ${ }^{33}$ This clause then became a part of the new contract; in effect the club had the right to renew the player's contract for an additional year in perpetuity. ${ }^{34}$ The reserve rule prevented a player from moving to another team of his own volition. A player's only options were to play for the same team for his entire career, to wait (or hope) to be traded, or to retire.

\section{The One Year Option Rule and the Rozelle Rule. Free agency} began in 1947 when the NFL replaced the perpetual reserve clause contained in the Standard Player Contract with the "one year option" rule. Under that rule, the clubs had the same right to renew a player's contract as they had under the reserve rule system, except that the renewal clause was restricted to a one-time use: "[A]fter such renewal this contract shall not include a further option to the Club to renew the contract." 35 Therefore, after a club exercised its one year option, a player would be free to negotiate with, and enter into a contract with, any other team. The player would be a free agent, not subject to any frec agency restrictions. The first player to switch teams through this system was R.C. Owens in 1962.36 As a result, the stage was set for unrestricted free agency.

The owners, however, avoided an unrestricted free agency system when they proposed, and the NFLPA agreed, to make the "Rozelle Rule" part of the new collective bargaining agreement. The Rozelle Rule allowed the NFL Commissioner, then Pete Rozelle, at his discretion, to award compensation froin the team signing a free agent to the team losing the player, unless the two teams came to a prior agreement as to compensation. ${ }^{37}$

33. J. DWorkin, Owners versus Players: Baseball and Collective Bargaining 249 (1981).

34. Id.

35. Id.

36. R.C. Owens completed his contract with San Francisco, played out his option year, and then signed with the Baltimore Colts in 1962. Mackey v. NFL, 407 F. Supp. 1000, 1003 (D. Minn. 1975), aff'd in part, 543 F.2d 606 (8th Cir. 1976).

37. The Rozelle Rule was adopted by NFL clubs in 1963 as an amendment to the League's Constitution:

Any player, whose contract with a League Club has expired, shall thereupon become a free agent and shall no longer be considered a meinber of the team of that club following the expiration date of such contract. Whenever a player, becoming a free agent in such manner, thereafter signs a contract with a different club in the League, then unless inutually satisfactory arrangements have been concluded between the two League clubs, the Commissioner may name and then award to the former club one or more players, from the Active, Reserve, or Selection List (including future selection choices) of the acquiring club as the Commissioner in his sole discretion deems fair and equitable; any such decision by the Commissioner shall be final and conclusive.

Id. at 1004 (quoting Article 12.1(H) of the NFL Constitution and By-Laws (1963)). 
The NFLPA later challenged the Rozelle Rule on antitrust grounds in Mackey v. NFL ${ }^{38}$, the NFLPA's first antitrust suit concerning free agency restrictions. In Mackey, the Eighth Circuit held that the Rozelle Rule violated Section 1 of the Sherman Act as an unreasonable restraint on trade. ${ }^{39}$ Specifically, the court concluded that the Rozelle Rule:

significantly deters clubs from negotiating with and signing free agents; ... decreases players' bargaining power in contract negotiations; ... that players are denied the right to sell their services in a free market, which results in lower salaries; ... and that absent the Rozelle Rule, there would be increased moveinent in interstate commerce of players from one club to another. ${ }^{40}$

The court recognized that the owners had a legitimate need to inaintain coinpetitive balance in the NFL, but concluded that even if the restriction enhanced competitive balance, the Rozelle Rule was too restrictive to serve any legitimate purpose. ${ }^{41}$

The court found three defects with the Rozelle Rule. First, the rule was overly broad. The Rozelle Rule was enacted to prevent the harmful effects of star players switching teams, but it applied equally to all NFL players, even below-average players. Second, the rule was too restrictive because it was unlimited im duration, operating as a perpetual restriction on a player's ability to inarket his services throughout his career. Finally, the rule was not accompanied by procedural safeguards. There was no way for the teams or players to know what compensation would be required for a specific player. Moreover, the NFL players liad no imput in determining what constituted fair compensation. ${ }^{42}$

3. Compensation and the Right of First Refusal. As part of a settlement in the Mackey case, the owners and the NFLPA proposed new forms of free agency restrictions that later becaine part of the 1977 collective bargaining agreement. Under the 1977 agreement, the free agent's team possessed a right of first refusal, that allowed it to match any interested club's offer and thus to retain the player. ${ }^{43}$ The agreement also set forth a compensation sclieme im which the team signing a free agent compensated the team losing the player with draft clioices. The

\footnotetext{
38. 543 F.2d. 606,609 (8th Cir. 1976).

39. Id. at 622 .

40. Id. at 620 .

41. Id. at 622 .

42. Id.

43. See infra note 49 for definition (1977 agreement not available, but provision similar to 1982
} agreement). 
number and level of draft choices depended on the free agent's years in the league and new salary. ${ }^{44}$

Fifteen of the players who were parties in Mackey objected to the inclusion of the compensation scheme and right of first refusal in the collective bargaining agreennent as part of the settlement. 45 These players argued that the proposal failed to cure the defects of the Rozelle Rule. ${ }^{46}$ However, the reviewing court approved the plan because it met the criteria of a valid class action settlement: the plan was not illegal to a legal certainty. ${ }^{47}$ The coinpensation scheme and right of first refusal were thus incorporated into the 1977 collective bargaining agrecinent. In approving the settlement, the court was not required to consider whether every provision of the plan would be reasonable under the Sherman Act or immune by reason of the labor exemption. ${ }^{48}$ Therefore, the court's approval is not determinative of whether these restrictions violate the Sherman Act.

The inost recent NFL collective bargaining agreement, sigued in 1982, retained a right of first refusal ${ }^{49}$ and a compensation scheme in which the team signing a free agent coinpensated the team losing the player with draft choices. The only change in the compensation system froin the previous collective bargaining agreennent (made primarily to adjust for inflation) was that the compensation required when a free agent was given a particular salary was reduced. ${ }^{50}$

44. See infra note 50 for a description of the compensation scheme in the 1982 agreement. Although the actual numbers were different, the compensation system in the 1977 agreement was functionally the same as that in the 1982 agreement.

45. Alexander v. NFL, 1977-2 Trade Cas. (CCH) If 61,730, at 72,998 (D. Minn. 1977), aff'd sub nom. Reynolds v. NFL, 584 F.2d 280 (8th Cir. 1978).

46. Id.

47. Id. at $72,998-73,000$.

48. Id. at 73,002 .

49. 1982 NFL Collective Bargaining Agreement, art. XV, $\S \S 1-10$. The right of first refusal functions as follows: An NFL player's contract expires on February 1 of a given year. Id. § 2 . If the NFLPA receives an offer from a new club to sign a free agent and the free agent finds it acceptable, the NFLPA, on or before April 15 of that year, gives the player's old club a completed Offer Sheet stating the principal terms. Id. § 3. "[T]f, within seven days from the date it receives an Offer Sheet, the veteran free agent's old club does not give to the NFLPA a first refusal exercise ... the player and the new club will be deemed to have entered into a binding agreement, which will be promptly formalized in an NFL player contract ...." Id. $\S 5$.

50. The agreement stipulated the following seheme (see table below), which was required if the free agent's old team chose not to exercise its right of first refusal within seven days of receiving the offer sheet. A player had to complete at least three years of NFL service to be eligible for free agency. Players with minimum salary offers below $\$ 80,000$ required no compensation. Different salary ranges applied for the 1982-1984 and 1985-1987 seasons (latter in parentheses). The table shows the range for players witl three years NFL service. 
4. Plan B. The 1982 free agency restrictions were followed through the 1987 season, and though the NFL played without a collective bargaining agreement after the 1987 strike, the same restrictions were used throughout the 1988-1989 season. With the antitrust suit still pending, and after both sides had inade several proposals, ${ }^{51}$ the owners modified the system by unilaterally imposing Plan B for the 1989-1990 season. ${ }^{52}$ Under Plan B, the owners may protect thirty-seven players on their rosters (the NFL allows forty-seven man rosters; forty-five players suit up for each game). ${ }^{53}$ Each protected player is subject to the same form of compensation as under the 1982 agreement, as well as a right of first refusal..$^{54}$ For the remaining unprotected players, however, there is neither a compensation requirement nor a right of first refusal; the players become completely unrestricted free agents from February 1 until April 1.55 The teams must protect the thirty-seven players according to a prescribed formula. ${ }^{56}$ The immediate impact of Plan B on player movement has been phenomenal: In 1989, 229 of the 619 unconditional free

\begin{tabular}{ll} 
FREE AGENT'S NEW SALARY & COMPENSATION \\
\cline { 2 - 2 }$\$ 80,000-94,999(100,000-119,999)$ & 3rd round draft choice \\
$\$ 95,000-109,999(120,000-139,999)$ & 2nd round draft choice \\
$\$ 110,000-149,999(140,000-179,999)$ & 1st round draft choice \\
$\$ 150,000-199,999(180,000-229,999)$ & 1st \& 3rd round choice \\
$\$ 200,000-249,999(230,000-279,999)$ & 1st \& 2nd round choice \\
over $\$ 250,000$ (over 280,000) & Two consec. 1st round choices
\end{tabular}

Id. Each end of the salary range increases by $\$ 10,000$ for each additional year of service beyond the minimum three. For example, in 1982, if a free agent had four years' experience and a salary in the $\$ 90,000-104,999$ range, his new team would have to give up a third-round draft choice.

51. Management originally implemented a more restrictive Plan $B$, whereby playoff teams, the middle tier of teams, and the eight worst teams could protect 40, 42, and 44 players respectively. Clubs Set Standby Plan to Free Fringe Players, Wash. Post, Jan. 12, 1989, at B6, col. 1. The owners also proposed that no player be eligible for free agency until his fourth season, and that quarterbacks, field goal kickers, and players who play 50\% of the time also be ineligible for free agency. NFL Notebook: Club Owners to Meet to Discuss Free Agency, Wash. Post, Jan. 16, 1988, at C4, col. 2.

The NFLPA had also made prior proposals. Under their West Coast Plan, players in their first 7 NFL seasons would be bound by the 1987 systen, players in their 8th-10th years of service would be subject only to a right of first refusal, and after 10 years, players with expired contracts became unrestricted free agents. Zimmerman, On the Outside Looking In, SPORTS IllustraTED, Oct. 26, 1987, at 54-57. The NFLPA alternatively proposed that players with six or more years of NFL service be unrestricted frec agents, with the service requirement dropping each year, to a minimum of three years by 1992. NFL Union Proposes Free Agency System. N.Y. Times, Dec. 14, 1988, at D26, col. 3. In this proposal the NFLPA would have allowed the owners to re-open the agrecment in any season in which salaries constituted over $70 \%$ of league-wide revenues. Id.

52. Controversial New Plan Goes into Effect Today, USA Today, Feb. 1, 1989, at 3C, col. 2.

53. Clubs Set Standby Plan to Free Fringe Players, supra note 51, at B6, col. 1. Injuries may increase the number of players a team has under contract beyond 47, but only 47 may be "active" at any one time. $I d$.

54. Controversial New Plan Goes into Effect Today, supra note 52, at 3C, col. 4.

55. Id. at 3C, col. 2.

56. See id. 
agents changed teams between February 1 and April 1.57 These results contrast sharply with the infrequent movement of free agents under the prior system. ${ }^{58}$ Despite the increased movement of Plan B free agents, however, no protected free agents have changed teams. The players contend that stars and average players still face the same free agency restrictions as before Plan B was implemented.59

It is possible that both the Plan B restrictions and the compensation and right of first refusal system contained in the 1982 agreement will be subject to antitrust scrutiny. Even though Plan B is a more lement system than that contained in the 1982 agreement (allowing more players to become unrestricted free agents), the 1982 restrictions still apply to protected players. The antitrust analysis for both systems will be similar because the majority of players face the same restrictions.

\section{B. Major League Baseball}

Major League Baseball (MLB) and the National Basketball Association (NBA), two sports leagues frequently compared to the NFL, have considerably more lemient free agency restrictions than does football. In one sense, the free agency system used by MLB is more restrictive than that of the NFL. In baseball, a player must have six years of Major League service to qualify for free agency; thus, many players are not elgible to use the free agency system. However, every other facet of the current MLB system is more unrestricted than the NFL system. ${ }^{60}$ The

\footnotetext{
57. Free-Agency Gambit Pays Off for Players, USA Today, Apr. 3, 1989, at 12C, col. 6.

58. Only two conditional free agents requiring compensation to their former team changed teams.

59. Unprotected Free Agents Are Getting All The Offers, USA Today, Mar. 2, 1989, at 3C, col. 2.

60. The development of free agency in baseball from inception to its present form has been extremely complex. Prior to 1975, MLB employed the reserve rule, as did the NFL. Baseball's reserve rule, like the NFL's prior to 1947, operated as a perpetual restriction. The Standard Player contract contained a clause stating that a club had the right to renew a player's contract for one year on the same terms as the prior contract. This clause then became part of the new contract, so that the club had the right to renew the player's contract for one year in perpetuity. J. DwoRKIN, supra note 33 , at 63 .

The initial antitrust challenge to the reserve rule, see Flood v. Kuhn, 407 U.S. 258 (1972), was unsuccessful because of baseball's exemption from the antitrust laws. See Federal Baseball Club v. National League, 259 U.S. 200 (1922) (granting exemption). The demise of the reserve rule came through arbitration proceedings: initially through a ruling in favor of Jim "Catfish" Hunter, and then ultimately through the Messersmith and McNally rulings. See R. BERRY, supra note 7, at 5358 (describing the arbitration cases).

These rulings opened the door to unrestricted free agency in baseball. The 1976 collective bargaining agreement, however, put some restrictions on free agency. A player had to have at least six years of Major League service to be eligible for free agency, and new teams had to compensate old teams with amateur draft picks. J. DwORKIN, supra note 33 , at 83 . However, the draft is less significant to MLB than to the NFL, where draft picks often play inımediately. In baseball, nearly
} 
compensation for free agents is less significant in MLB than in the NFL because MLB requires only amateur draft choices as compensation for lost free agents. ${ }^{61}$ The amateur draft plays a much less important role in baseball than in the NFL or the NBA, as draft choices ultimately play in the major leagues much less frequently than in the NFL or the NBA. ${ }^{62}$ Since the compensation level is lower, baseball teams mcur a smaller cost in signing free agents than do NFL teams. Unlike the NFL, no right of first refusal exists in MLB's free agency systein.

\section{The National Basketball Association}

NBA teams mcur no cost for signing free agents because the NBA's free agency system does not require any compensation for lost free agents. In order to sigu a free agent, however, an NBA team must comply with the NBA's salary cap restrictions. The salary cap prohibits a

all draft choices go to the minors; many never make the Major Leagues. Teams draft free agents in reverse order of their finish. P. STAuDOHAR, supra note 7 , at 34.

Free agency, and the form of compensation for lost free agents, dominated baseball's next collective bargaining session. Disagrecment over these issues resulted in the 1981 strike. Ultimately, the sides agreed to compensation from a pool of players, as opposed to allowing the team losing a player to pick a particular player from the team signing the free agent. The scheme was based on a ranking system, in which teams could protect 24 players on their rosters if they sigued a ranking free agent and 26 players if they did not. All unprotected players then went into a pool. Ranked players could attain Type A rankings, defined as those players in the top $20 \%$ of the League, or Type B rankings, for those in the next $10 \%$. Teams losing a Type A free agent received one pick from the frec agent pool plus an amateur draft choice. Teams losing a Type B free agent received two picks from the amateur draft, whereas teams losing any non-ranked player received one amateur draft choice. R. BERRY, supra note 7, at 73.

The 1985 baseball collective bargaining agreement modified the free agent system again. The eligibility requirement of six years of MLB service remained, but the free agent draft and profes. sional compensation system were abolished. Amateur draft choices were left as the only form of compensation. Baseball Strike is Settled; Games to Resume Today, N.Y. Times, Aug. 8, 1985, at B11, col. 4. This form of free agency remains in effect today, despite the turbulent negotiations over the 1990 agreement. Two proposals made by management during the 1990 negotiations are worth noting. First, the owners proposed a revenue sharing scheme between the owners and players, and a salary cap for a team's aggregate player salaries, similar to that used in the NBA. Revenue Sharing Has Baseball's Attention, Wash. Post, Sept. 5, 1989, at B2, col. 1. See generally Memorandum of Understanding betwecn NBA and National Basketball Players' Association, art. 111, $\$ C(1)$ (describing the NBA system forming the basis of the owners' proposal) [heremafter Memorandum]. Management also proposed an expense-sharing scheme among the owners, in which the owners share salary expenses for players with less than six years MLB service. Club Owners Working on a Plan to Share Salary Expenses, N.Y. Times, Sept. 10, 1989, at S3, col. 1. Player salary levels would then be based on service time and actual player statistics. Id. The 1990 agreement retained the free agent system adopted in the 1985 agreement, although it altered the structure of salary arbitration.

61. Baseball Strike is Settled; Games to Resume Today, supra note 60, at A1, col 3.

62. The only players drafted by the NFL and the NBA come directly from college and are proven players. Neither league employs a minor league-the players go directly to the big leagues. On the other hand, baseball players frequently get drafted out of high school and are not proven stars. Baseball also uses a minor league system, where drafted players almost always start their careers. 
team from spending more than the greater of fifty-three percent of revenues or an amount determined by the League, on player salaries. Teams may not sign free agents that would cause them to exceed this cap. ${ }^{63}$ Unlike the NFL's free agency system, which imposes added costs on teams signing free agents, the NBA's system simply limits the teams that are eligible to sign free agents. It is liarder for teams to sign the more expensive free agents (because the player's salary may push the team over the cap), but there is no penalty or compensation tliat must be paid to sigu a free agent. The NBA also employs the right of first refusal for players with fewer than five years of NBA service. 64 This feature allows a team to retain its potential free agents by matching otlier teams' offers to those players. ${ }^{65}$ As in both the NFL and MLB, free agency in the NBA lias struggled to develop. ${ }^{66}$

Three professional sports leagues, the NFL, NBA, and MLB, currently employ different free agency restrictions. None of the leagues lias an unrestricted system, but the level of the restrictions differs. The costs imposed on teams that sign free agents are much higher in the NFL than in the other sports, but NFL teams are not otherwise limited in which

63. Memorandum, supra note 60 , art. III, $\S \mathrm{C}(1)$.

64. P. StaudohaR, supra note 7, at 129.

65. Memorandum, supra note 60 , art. $1, \S$ A.

66. The NBA initially employed a perpetual reserve rule, see J. DwoRKIN, supra note 33, at 233, but abandoned it in 1976. The impetus for the change came from Robertson v. NBA, 389 F. Supp. 867 (S.D.N.Y. 1975), in which the court, although it declined to rule on the merits, strongly suggested that the reserve rule violated Section 1. Id. at 893-94. Free agency came in the 1976 collective bargaining agreement, which created two different policies to be instituted in two phases. From 1976 to 1980, the NBA used a compensation scheme similar to the Rozelle Rule. The NBA Commissioner determined a free agent's compensation level, which could consist of cash, draft choices, or players already in the NBA, if the two teams were mable to settle the matter among themselves. Looney, The Start of a Chain Reaction, SPORTS Illustrated, Feb. 16, 1976, at 18-20. From 1981 imtil 1986, however, the NBA was to abolish the compensation scheme and to employ a right of first refusal. Id.

In 1983 the two sides added revenue-sharing to the agreement and reaffirmed the right of first refusal. Memorandum, supra note 60 , art. $1, \S \mathrm{A}$. The owners agreed to pay at least $53 \%$ of all NBA revenues into player salaries. The owners also placed a maximum on the amoimt to be spent on player salaries-the greater of $53 \%$ of revenues or a designated amount. Id. art. 111, $\S \mathrm{C}(1)$. Technically, teams could not sign free agents if the player's salary put the team over its salary limit or if the team was already over the salary limit. Id.; see also NBA Strike Averted with Accord on 4Year Pact, N.Y. Times, Apr. 1, 1983, at A19, col. 5 (describing the system in detail). The agreement provides for several exceptions so that teams can find ways to sign free agents that would ordinarily put them over the salary cap. See P. STAudoHar, supra note 7, at 112 (deseribing a loophole in which a the team can mateh an offer to its free agent without affecting the salary cap); Memorandum, supra note 60 , at $\S \S 2 \mathrm{a}-\mathrm{g}$.

In 1988, the NBA negotiated a new collective bargaining agreement, currently in effect, that retains much of the past agreement. P. STAUDOHAR, supra note 7, 129. The agreement modified the right of first refusal, making it no longer applicable to "veteran" players who play out their second contract. Through the 1992-1993 season, players must have five years of NBA service to qualify as "veterans." For the 1993-1994 season, players are eligible after only four years of service. Id. 
and how many free agents they can sign. MLB requires players to wait longer to use the system, whereas the NBA limits which teams can use the system. The type of restriction, and the extent to which it curtails the use of the free agency system, are critical factors in evaluating the reasonableness of a restramt for Section 1 purposes. Moreover, as will be demonstrated, even if the three leagnes employed identical restrictions, the restrictions would produce different effects relevant to antitrust analysis. These differences result from the different economic structure of each league, which will be described by the statistical model in Section IV.

\section{Antitrust Laws Applicable to Free Agent Restrictions}

Before describing the assumptions that courts make about sports leagnes and the economics of various sports markets, it is essential to analyze the manner in which courts apply the antitrust laws-both in sports and non-sports settings.

The pressing issue in evaluating the legality of the free agency restrictions used in the NFL is whether or not the restrictions constitute a restraint of trade in violation of Section 1 of the Sherman Act. ${ }^{67}$ Section 1 was designed to eliminate restramts on trade by outlawing certain anticompetitive practices. ${ }^{68}$ In Powell, the NFLPA brought a Section 1 suit, claiming that the League's free agency restrictions restram trade.

\section{A. The Standard of Analysis Under Section 1 of the Sherman Act}

Section 1 of the Sherman Act by its own terms outlaws all restraints on trade. Since every commercial contract restrains trade to some extent, courts have interpreted Section 1 to prohibit only unreasonable restraints of trade. ${ }^{69}$ Courts may evaluate a Section 1 clann either as a per se violation or as a violation of the Rule of Reason standard. A per se violation exists when the court concludes, without looking at the possible

67. 15 U.S.C. $\S 1$ (1988).

68. Rosenbaum, supra note 27, at 749. By contrast, Section 2 of the Sherman Act, which states that "[e]very person who shall monopolize, or attempt to monopolize, or combine or conspire with any other person or persons, to monopolize any part of the trade or commerce among several States, or with foreign nations, shall be deemed guilty of a felony ...," 15 U.S.C. $\$ 2$ (1988), focuses on monopoly power and attempts to eliminate harmful concentrations of market power in a particular imdustry. Section 2 prohibits improper market domination by a single actor, see Weistart, League Control of Market Opportunities: A Perspective on Competition and Cooperation in the Sports Industry, 1984 DUKE L.J. 1013, 1036, and tries to prevent these actors from raising prices and restricting output. See Rosenbaum, supra note 27 , at 749-50.

69. See Arizona v. Maricopa County Med. Soc'y, 457 U.S. 332, 342-43 (1982); National Soc'y of Professional Eng'rs v. United States, 435 U.S. 679, 687-88 (1978); Board of Trade v. United States, 246 U.S. 231 (1918); Standard Oil Co. v. United States, 221 U.S. 1, 58 (1911). 
justifications and benefits of the restraint, that the restraint violates Section 1. By contrast, a Rule of Reason analysis evaluates the possible justifications for and benefits of the restraint on competition and determines whether the restraint is reasonable for Section 1 purposes. Characterization of a restraint as a per se violation avoids the burden and expense of a more complex Rule of Reason analysis on both the litigant and the judicial system. ${ }^{70}$ However, a per se determination requires a court "to make broad generalizations about the social utility of particular commercial practices." 71 A court will only classify restraints as per se violations if it lias had considerable experience dealing with the restrictions at issue and witl the industry in which the restriction is used.72 Practices trcated as per se violations of the Sherman Act include group boycotts and price fixing.

With regard to sports cases, certain federal district courts lave found that player restrictions constitute per se violations of the Act, ${ }^{73}$ but no appellate court has done so. Instead, appellate courts have used the Rule of Reason standard, primarily because of the several unique features of the sports industry. ${ }^{74}$ First, the industry is atypical because teams within a league are not competitors in the traditional sense; because the teams want each otlier to succeed financially, the league reseinbles a joint venture. ${ }^{75}$

Second, there is uncertainty in the industry about the impact of and novelty of free agency restraints. ${ }^{76}$ The uncertainty regarding the impact of free agency restrictions results because courts are unable to make broad generalizations about sports inarkets. In addition, courts have only infrequently dealt witl free agency restrictions. Powell is the first case since Mackey in whicl a court will address the issue.

These unique features suggest that the current NFL restrictions should and will be judged using the Rule of Reason standard. Moreover, the Mackey court stated that a Rule of Reason standard is more appropriate than a per se analysis if the free agency restraint in question does

70. Continental T.V. Inc. v. GTE Sylvania, Inc., 433 U.S. 36, 50 n.16 (1977).

71. Id.

72. Broadcast Music, Inc. v. CBS, 441 U.S. 1, 9 (1979).

73. See, e.g., Mackey v. NFL, 407 F. Supp. 1000 (D. Minn. 1975), aff'd in part 543 F.2d 606 (8th Cir. 1976) (Rozelle Rule a per se violation); Robertson v. NBA, 389 F. Supp. 867, 896 (S.D.N.Y 1975) ("perpetual reserve system would also appear to be a per se violation," though settlement precluded determination on merits); Denver Rockets v. All-Pro Management Inc., 325 F. Supp. 1049 (C.D. Cal. 1971) (NBA rule which forbade anyone to play for or negotiate with any NBA team until four years after he or his class graduated high school deemed per se violation).

74. See Smith v. Pro Football, Inc., 593 F.2d 1173, 1177-82 (D.C. Cir. 1979); Mackey v. NFL, 543 F.2d 606, 618-20 (8th Cir. 1976).

75. Mackey, 543 F.2d at 619.

76. White Motor Co. v. United States, 372 U.S. 253, 269 (1963). 
not completely eliminate competition for players' services. ${ }^{77}$ The restrictions in the NFL do not completely restrict competitions for players' services.

\section{B. Rule of Reason Analysis}

When applying Section 1 scrutiny to the NFL's free agency restrictions, the courts will generally analyze three factors: the restrictions' impact on player mobility, their effect on professional football as a product, and their effect on consumer welfare. The overriding purpose of the courts' analysis is to determine the restrictions' total impact on competition.

1. Total Impact on Competition. Section 1 of the Sherman Act is designed to foster competition:

The Sherman Act was designed to be a comprehensive charter of economic liberty aimed at preserving free and unfettered competition as the rule of trade. It rests on the premise that the unrestrained interaction of competitive forces will yield the best allocation of our eeonomic resources [and] the lowest prices, the highest quality ... .; the pohicy unequivocally laid down by the Act is competition. ${ }^{78}$

The definition of competition in sports leagues, however, is unsettled. Therefore, the key issue in the controversy over NFL free agency restrictions is the judicial definition of competition.

In sports contexts, courts typically have inquired into the effects of free agency restrictions on the labor market; in other words, competition has been measured narrowly-in terms of the players' free movement. ${ }^{79}$ Because any restraint on free agency necessarily inhibits some player moveinent the restrictions always will be characterized as anticompetitive under such an analysis. ${ }^{80}$ This analysis iguores the coinpetitive effects that free agency restrictions have on the league as a product and on overall consumer welfare. Existing precedent suggests that the best way to determine whether competition is enhanced or stifled is to focus on all competitive effects created by a restraint on trade.

In an early case applying the Rule of Reason standard, the court held that restrictions should be evaluated upon their total impact on

77. Mackey, 543 F.2d at 619.

78. Northern Pac. Ry. Co. v. United States, 356 U.S. 1, 4-5 (1958).

79. Mackey, 534 F.2d at 616-18; Robertson v. NBA, 389 F. Supp. 867, 883-84 (S.D.N.Y. 1975).

80. Rosenbaum, supra note 27 , at 747-48 (impossible for restraint to be pro-competitive when looked at this way); Note, Of Hoops, Labor Dupes and Antitrust Ally-Oops: Fouling Out the Salary Cap, 62 IND. L.J. 95, 121-24 (1986). 
competition. ${ }^{81}$ Courts have also recognized that, when judging a restraint, the facts peculiar to the business involved must be considered. In Board of Trade v. United States, 82 the Supreine Court apphed Section 1 scrutiny to uphold a call .rule at a commercial center involving grain trading. The call rule prohibited grain trading between the close of the call and the opening of the next business day, thereby curtailing the time when people could trade. The Court stated:

The true test of legality is whether the restraint imposed is such as merely regulates and perhaps thereby promotes competition or whether it is such as may suppress or even destroy competition. To determine that question the court must ordinarily consider the facts peculiar to the business to which the restraint is applied; its condition before and after the restraint was imposed; the nature of the restraint and its effect, actual or probable. The history of the restraint, the evil believed to exist, the reason for adopting the particular remedy, the purpose or end sought to be attained, are all relevant facts. ${ }^{83}$

The Court noted several benefits of the rule that made it reasonable for Section 1 purposes. These benefits included bringing buyers and sellers into direct relations, creating set hours for market trading, and distributing business to more grain dealers. ${ }^{84}$

These holdimgs suggest that courts should consider a restriction's total effect on competition for Section 1 purposes. They also suggest that courts should inquire into the peculiar characteristics of sports industries, and the NFL in particular, when evaluating the competitive effects of free agency restrictions. As will be demonstrated by a statistical model, the characteristics of various sports leagues are different, and courts should take each sport's particular characteristics into account.

The standard the Supreine Court set forth in Board of Trade shifted to a more economically-oriented approach in National Society of Professional Engineers v. United States. 85 The Supreme Court there reiterated that the appropriate question is whether a challenged agreement promotes or suppresses competition, ${ }^{86}$ but its analysis focused on economic concepts $\mathrm{m}$ which it weighed coinpetitive and anti-competitive forces. ${ }^{87}$

81. 24 Eng. Rep. 347 (1711). Mitchel upheld a restriction that deprived the public of potential competition in the short run on the grounds that the long run benefit to the pnblic outweighed it. See also National Soc'y of Professional Eng'rs v. Umited States, 435 U.S. 679, 688-89 (1978) (describing Mitchel).

82. 246 U.S. 231 (1918).

83. Id. at 238.

84. Id. at $240-41$.

85. 435 U.S. 679 (1978).

86. Id. at 691 .

87. Id. at 690 n.16, 691-92; see also Rosenbanm, supra note 27, at 737 (interpreting Professional Engineers to say that a court must "balance these positive economic resnlts against the alleged decrease in counpetition that inspired the lawsuit in the first instance"). 
In Professional Engineers, the Court ruled that a society of engineers' agreement that prohibited any member from negotiating and submitting a bid for its engineering services until a particular engineer was selected for the job constituted a Section 1 violation. ${ }^{88}$ The Society argued that the agreeinent was necessary and reasonable because unrestrained bidding created incentives for engineers to offer lower prices, thus causing a corresponding decrease in the quality of engineering services and significantly threatening public safety, health, and welfare. ${ }^{89}$ Although the Court recognized these potential effects, it stated that the purpose of the Sherman Act was to foster competition, and that even if monopolistic practices better promote trade and commerce than competition does, those practices are still not reasonable for Sherman Act purposes. 90

Professional Engineers unequivocally states that the restriction's impact on competition should be the ouly consideration for Section 1 purposes; all other justifications for the restraint are irrelevant. Professor Weistart indicates that Professional Engineers, when considered alone, gives the impression that where a restraint is devised by a group of actors, the restraint is justified only if competition among those actors is enhanced. ${ }^{91}$ In terms of frec agency restrictions, Weistart suggests that this interpretation of the case would mean that the restriction's inpact on inter-club competition (i.e., competition for player services) is the only relevant consideration for Section 1 purposes. ${ }^{92}$

This application of Professional Engineers to free agency restrictions is unsound. First, Professional Engineers emphasizes that the only relevant inquiry is the restramt's impact on competition. Second, Professional Engineers focuses on an agreement ainong members of an engineering society; as described in the next section, the sports market is far different than the engineering industry, or any typical industry, because the respective teains need each other to produce their product. Therefore, although Professional Engineers requires consideration of a free agency restriction's impact on inter-club competition, it does not preclude consideration of the effect of the restriction on other forms of competition in the sports inarkets-such as the product market and consumer welfare. Furthermore, as Professor Weistart indicates, later cases reveal that a free agency restriction may be procompetitive for Section 1 purposes in areas other than effects on inter-club competition for player

\footnotetext{
88. Professional Engineers, 435 U.S. at $692-93$.

89. Id. at 693-96.

90. Id. at 695.

91. See J. Weistart \& C. Lowell, The Law of Sports § 5.07, at 112 (Supp. 1985).

92. Id.
} 
services. ${ }^{93}$ The following sections discuss these cases and offer additional reasons that factors other than the impact on players are relevant for Section 1 purposes.

2. Competitive Impact on the League as a Product. Several cases indicate that the effect that free agency restrictions have on the league as product, i.e., the competitiveness of NFL football in the entertainment market, is a relevant consideration under Section 1 of the Sherman Act.

In Continental T.V., Inc. v. GTE Sylvania, Inc., ${ }^{94}$ the Supreme Court ruled that the Rule of Reason was the appropriate standard to evaluate certain vertical restrictions between a inanufacturer and its retailer under Section 1 of the Sherman Act. The retailer alleged that GTE Sylvania, the inanufacturer, violated Section 1 by entering into and enforcing franchise agreements that prohibited the sale of Sylvania products other than from specified locations.95 The Court stated that "[i]nterbrand competition ... is the primary concern of antitrust law."96 Moreover, the Court acknowledged that the "degree of intrabrand competition is wholly independent of interbrand competition" and also the potential for an increase in interbrand competition to occur at the same time as a reduction in imtrabrand coinpetition. ${ }^{97}$ Put in these terms, the NFL is engaged in interbrand coinpetition with other forms of entertaininent, whereas individual teams and players are engaged in intrabrand coinpetition, competing with each other in terms of players, inarket shares, and playing success. Read in conjunction with Professional Engineers, Continental T.V. imphes that an increase in interbrand-not intrabrand-coinpetition is the type of procompetitive effect that can justify what would otherwise appear to be an unreasonable restranit of trade under Section 1. Thus, if free agency restrictions imcrease the competitiveness of the NFL as a product versus other forms of entertaininent, the restrictions inay be reasonable for Section 1 purposes.

NCAA v. Board of Regents, 98 decided after Professional Engineers, indicates that the impact of free agency restrictions on the NFL as a product is a relevant Section 1 consideration. In Board of Regents, the Court found that the NCAA's plan to televise football games of its inember institutions violated Section 1 of the Sherman Act. The plan limited both the total anount of televised intercollegiate football games and the

93. Id. at $112-13$.

94. 433 U.S. 36 (1977) (decision by Supreme Court prior to that in Professional Engineers, but later affirmed on remand by circuit court subsequent to announcennent of Professional Engineers).

95. Id. at 40.

96. Id. at 52 n.19.

97. Id.

98. 468 U.S. 85 (1984). 
number of games that any one member school could televise. No NCAA meinber was permitted to sell its television rights except in accordance with the plan. Certain schools that had privately negotiated a contract with another network challenged the plan's legality under Section 1 after the NCAA threatened them with disciplinary action. ${ }^{99}$ The NCAA defended the plan on the ground that its purpose was to decrease the adverse effect of hive television on football game attendance. ${ }^{100}$ The Court found that the plan actually decreased the competitiveness of college football television rights, ${ }^{101}$ and that the plan was not necessary to enable the NCAA to penetrate the television market through an attractive package sale. ${ }^{102}$

The Court noted two important limitations on its decision. First, it stated that ccrtain rules and restrictions that "preserve the character and quality of the 'product' of college football enable a "product to be inarketed which might otherwise be unavailable."103 Second, the Court stated that it is reasonable to assume that most of the regulatory controls of the NCAA are justifiable means of fostering competition among athletic teams and therefore procompetitive because they enhance public interest im intercollegiate athletics."104 Professor Weistart sees this decision as explaining and correcting Professional Engineers by making it clear that a restraimt inay be procoinpetitive for Section 1 purposes by enhancing the competitiveness of the rule devising group (i.e., the NFL) against other producers of competing products. ${ }^{105}$ Weistart drew this conclusion from Board of Regents' statement that certain restrictions are necessary to define the product and preserve its distinctiveness against other competing products. ${ }^{106}$ Whether or not such a clarification of the Professional Engineers test was necessary, Board of Regents recognizes that even if a restriction reduces internal competition, the effect on the product itself inust be analyzed.

Board of Regents, as Weistart indicates, left open at least one question about the evaluation of a free agency restriction for Section 1 purposes: the way in which the procoinpetitive and anticoinpetitive effects should be balanced. ${ }^{107}$ The Court im Board of Regents determined that the alleged procompetitve effects on the product produced by the rule

99. Id.

100. Id. at $89-90$.

101. Id. at 114 .

102. Id. at 115 .

103. Id. at 102.

104. Id. at 117.

105. J. WeisTART \& C. LOWELL, supra note 91, at 112.

106. Id. at 113 .

107. Id. 
were illusory; therefore, there were no procompetitive effects to be balanced against the anticompetitive effects. ${ }^{108}$ According to Professional Engineers, the proper way to balance pro- and anticompetitive effects is objectively and quantitatively. ${ }^{109}$ The statistical model developed in Part IV, which determines the free agency restriction's impact on the players and the NFL as a product, enables the use of the strict econormic balancing approach conteinplated by Professional Engineers. Thus, the model completes the picture for the Section 1 analysis.

Fimally, the reasoning behind the single entity defense to a Sherman Act violation also supports the conclusion that free agency restrictions' impact on the sports league as a product is relevant to Section 1 scrutiny. Proponents of the defense argue that the individual league members im any sports league cannot couspire to restrain trade because the league is an mdivisible product. ${ }^{110}$ Since a Section 1 violation requires a conspiracy, or a unity of actors, this reasoning, known as the "single entity defense," would inake Section 1 inapplicable to restrictions on free agency. Under the single entity defense, no internal rule, deeision or pohicy of the league, no inatter how egregious, thrat relates to the business of producing its sports product could violate Section 1 because of the absence of the requisite number of actors. ${ }^{111}$ These commentators beheve that the single entity defense should apply to sports leagues because only the League, acting as an entity, can produce the product. Unlike individual competitors $\mathrm{m}$ a traditional business, no individual team is able to produce a product without the other teams and the League. ${ }^{112}$ The only case to rule on the single entity defense in a sports setting, Los Angeles Memorial Coliseum Commission v. NFL, ${ }^{113}$ rejected the single entity argument, ${ }^{114}$ but that case was followed by a great deal of critical hiterature.115

Whether one accepts tlie single entity defense in toto, the reasoning underlying the argument implies, at the very least, that the coinpetitive effect of free agency restrictions on the League as a product is a relevant consideration for a Section 1 analysis. The focus of the single entity de-

108. 468 U.S. 85, 119-20 (1984); see also J. WEISTART \& C. Lowell, supra note 91, at 113.

109. See supra notes $85-92$ and accompanying text.

110. See Grauer, Recognition of the National Football League as a Single Entity Under Section 1 of the Sherman Act: Implications of the Consumer Welfare Model, 82 MrCH. L. REv. 1 (1983) (NFL as single entity and rules should be considered only in light of their impact on consumer wealth); Roberts, Sports Leagues and the Sherman Act: The Use and Abuse of Section 1 to Regulate Restraints on Intraleague Rivalry, 32 UCLA L. REv. 219 (1984) (look to NFL as a single entity; leaving decisions to league rather than courts is efficient); Rosenbaum, supra note 27, at 741 .

111. See Roberts, supra note 110, at 225.

112. See id. at 227-31.

113. 726 F.2d 1381 (9th Cir. 1983).

114. Id. at 1387-90.

115. See Roberts, supra note 110; Weistart, supra note 68, at 1013. 
fense is not on the separate actors, but on the product itself. Although Los Angeles Coliseum indicates that it is unlikely that a court will apply the single entity defense in this context, one must bear in mind that the League does not coinprise a unity of actors in the traditional sense. Each member of the League inust rely on every other meinber to produce the League's product; in inore traditional industries, each producer need not rely on other similar producers to produce his product. Therefore, courts should consider the overall product market effects created by free agency restrictions.

3. Competitive Impact on Consumer Welfare. In evaluating free agency restrictions under Section 1 of the Sherman Act, courts should also consider the restrictions' impact on consuuner welfare. Several commentators have argued that consunier welfare is, $m$ fact, the primary goal of antitrust enforcement pohicy. ${ }^{116}$ In a critical examination of the Sherman Act, Judge Robert Bork concluded that consumer welfare is the only relevant consideration. ${ }^{117}$ Judge Bork used the legislative history of the Sherman Act to justify his conclusion. For example, he notes that Senator Sherman, the chief promoter of the Act, einphasized consumer welfare during debates concerning each bill he proposed regarding the Act. Bork quotes Senator Sherman as stating that the bill was designed to prohibit activities that "prevent full and free competition,' and . . . those 'desigued, or which tend, to advance the cost to [the] consumer." "118 Practical considerations also suggest that consumer welfare should be the focus of antitrust analysis. Professor Grauer states that simce busmesses need to predict the consequences of their actions to operate effectively, a focus on consumer welfare is advantageous in that it gives businesses a much-needed objective legal standard to which they can conform. ${ }^{119}$

Several Supreine Court cases support the use of consuiner welfare analysis in judicial application of the antitrust laws. ${ }^{120}$ For example, in

116. See Bork, Legislative Intent and the Policy of the Sherman Act, 9 J.L. \& EcoN. 7, 11 (1966); Grauer, supra note 110; Posner, The Rule of Reason and the Economic Approach: Reflections on the Sylvania Decision, 45 U. CHI. L. REV. 1, 13 (1977); Roberts, supra note 110. Professor Peritz states that the Sherman Act never mentions competition, that the focus of the Act should not be on competition, and that not all effects produced by a restraint should be valued equally under the Act. Peritz, A Counter-History of Antitrust Law, 1990 DukE L.J. 263, 270. He also states that the distributional effects of the restraint and faimess are the real crux of the antitrust laws. Id. at 317 20. Accordingly, Peritz argues that gains that inure to monopoly type producers, rather than to the public, should not be valued under the Sherman Act. Id.

117. Bork, supra note 116, at 11.

118. Id. at 15 (quoting 21 CoNG. REc. 1765 (1890)).

119. Grauer, supra note 110 , at 10.

120. See Roberts, supra note 110 , at 220 n.4 (citing cases). 
Reiter v. Sonotone Corp., 121 the Court cited with approval Bork's finding that the floor debates over the Sherman Act suggest that Congress designed the Act as a "consumer welfare prescription." 122 In Broadcast Music v. $C B S,{ }^{123}$ the Court, presented with the issue of whether a group of publishers had violated the Sherman Act via price fixing, indicated that the key question was whether the practice always, or almost always, restricts competition and decreases output. ${ }^{124}$ The Court's denial of a Section 2 claim in Copperworld Corp. v. Independent Tube Corp., ${ }^{125}$ summed up the Court's attitude. In analyzing the effects of one company's capture of another's custoiners due to the latter's inefficient practices, the Court stated that " $[t]$ his . . . is precisely the sort of competition that proniotes the consumer interests that the Sherman Act aims to foster." 126

Although not every decision cited above involves a Section 1 claim, the use of consumer welfare analysis in applying any section of the Sherman Act provides support for its consideration in a Section 1 analysis. Moreover, the Supreine Court has stated its approval of consumer welfare analysis for Section 1 claims. In NCAA v. Board of Regents, ${ }^{127}$ the Court reasoned that the effects of the restraint on prices, output, and quality were relevant considerations for Section 1 cases. ${ }^{128}$ Moreover, the Court found restraints that generally "widen consumer choice" are procompetitive. ${ }^{129}$ In Board of Regents, the Court ruled that the television plan, which restricted the number of college football gaines televised for both individual schools and for the NCAA as a whole, constituted a Section 1 violation largely because the plan decreased consumer consumption. The Court suggested that the outcome would be different if the plan increased output and decreased the price of televised gaines. ${ }^{130}$

Consumer welfare analysis does not autoinatically suggest that all NFL free agency restrictions will be procoinpetitive and thus satisfy Section 1. Rather, consumer welfare analysis changes which effects produced by a given restraint that courts should consider in their Section 1 analysis. Similarly, different considerations apply when the focus is on the product market. Courts cannot simply inaintain a focus on the ef-

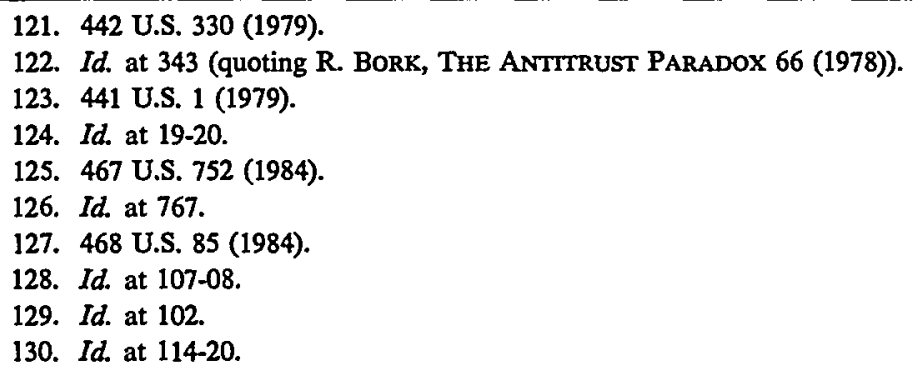


fects of a restraint on player mobility and salaries. Courts must consider a restriction's overall impact on spectator consumption of football-imcluding the restraint's effect on ticket prices, the number of gaines played, and the NFL's substitutability with other products. These effects are considered in the next section.

Once it is known which forms of competition are relevant to analyzing restrictions subject to Section 1 of the Sherman Act (the labor market, the NFL as a product, and consumer welfare), it is essential to understand how particular free agency restrictions will affect each form of competition. An understanding of the economics of sports markets is necessary to accomplish this task. The next section develops a model that describes the sports markets and allows quantification of the mipact of free agency restraints on the relevant factors. Even for those who rigorously adhere to the view that all forms of competition should not be weighed equally for antitrust purposes, the model is still highly relevant because it describes the actual effects of free agency restrictions. Although this Note gives eacli form of competition equal weight, it is also possible to use the model's objective analysis attaching different weiglits to the various forms of competition.

\section{The Statistical Model}

\section{A. Purpose of the Model}

The previous section indicates that courts must consider several kinds of competitive effects to properly evaluate a Section 1 claim. To better understand how the free agency rcstraints affect the various aspects of competition, it is helpful to quantify these effects. A statistical model adapted for this purpose can lielp quantify the impact of an individual player on a team's intra-league competitiveness, individual teain competitiveness on individual team revenue, and an individual player on overall team revenues. The purpose of the model is to facilitate accurate economic assumptions about the way in which a sports market works, and to help determine whetlier the restriction is reasonable for purposes of Section 1 of the Slierman Act. Although this Note focuses on the NFL collective bargaining agrecment, an analysis of other sports leagues is necessary to understand, and to put in perspective, the workings of the NFL. The NBA and MLB are used for the comparison.

\section{B. Mechanics of the Model}

The statistical model, whicli ultimately quantifies an individual player's effect on overall team revenues, was broken down into two pliases, or two regression equations. The reasoning behind the model 
was to see how one player could affect a team's winning percentage and to see how this change in team performance affected that team's total revenues. Some players, however, may affect a team's revenues irrespective of how that player affects his team's winning percentage. These players are the stars, the Michael Jordans of the world, the players that people come to see just to see, regardless of the teams for which they play. The model controls for this factor when it determines a player's impact on revenues.

The first regression determines how an individual player affects a team's winning percentage. ${ }^{131}$ This was determined by seemg how

131. The first stage of the model, which examines how an individual affects team performance, uses a regression that analyzes changes in a specific team's winning percentage over two consecutive seasons ("CHWP") against the corresponding changes in that team's statistics. The regression requires numerous sets of figures for each equation. For example, suppose the Jets have a winning percentage of .500 in 1988 and their four overall team statistics were A, B, C, and D, and in 1987, the Jets had a winning percentage of .400 with statistics $\mathrm{W}, \mathrm{X}, \mathrm{Y}$, and $\mathrm{Z}$. The set of figures used in the regression would be winning percentage change (.100), against the change in statistics (A-W, B$\mathrm{X}, \mathrm{C}-\mathrm{Y}$, and $\mathrm{D}-\mathrm{Z}$ ). The model uses changes of winning percentage and statistics within teams rather than simply one team's statistics and winning percentage in a given year, because the former method holds the specific team constant. Analyzing changes within a team recognizes the intangibles of winning and holds team chemistry and attitude constant, whereas the other inethod does not.

In addition to changes in team statistics, the inodel also includes whether the team was not a contender in one year and became one the following year ("DCONT") or vice-versa ("DOUT"). The theory is that players in a playoff battle give greater effort as the season closes; therefore, the team is likely to win more games during the latter portion of the year. To determine whether a team was a contender, the model considers whether the team was within " $X$ " number of games with approximately $10 \%$ of the season remaining. "DCONT" indicates that the team was a contender in the given year, but not the previous year. "DOUT" indicates that the team was not a contender in the current year, but was in the previous year. When the team's contender status failed to change during the year, no variable was required.

In the NFL, the regression for CHWP was run on both the changes in the team's statistics ("1") and its opponent's statistics against them ("2") for rushing yards ("CHRUSH1," "CHRUSH2"), passing yards ("CHPASS1," "CHPASS2"), turnover ratio ("CHTO1," "CHTO2"), penalty yards ("CHPEN1," "CHPEN2"), field goal percentage ("CHFG1," "CHFG2"), and opposition winning percentage ("CHOPWP"). Changes in the winning percentage of team A's opposition affects team A's own winning percentage, because each NFL team plays different teams each year. A team with a tough schedule for a given year is less likely to win games. This effect does not occur in either baseball or basketball because each team plays the same teams each year. The following equation resulted:

$$
\begin{aligned}
& \text { CHWP }=[(.0001557) \text { (CHRUSH1) }-(.0000516)(\text { CHRUSH2) }]+[(.0000817) \text { (CHPASS1) }- \\
& (.0000214)(\text { CHPASS } 2)]-[(.001) \text { (CHTO1) }+(.000043) \text { (CHTO2) }]+[(.000025) \text { (CHPEN1) }+ \\
& (.000204)(\text { CHPEN2) }]+[(.0389)(\text { CHFG1) }-(.3316)(\text { CHFG2) }]-(.6044)(\text { CHOPWP })+ \\
& {[(.1138)(\mathrm{DCONT})-(.1327)(\mathrm{DOUT})]} \\
& \mathrm{n}=84 \quad \mathrm{R} 2=.505 \quad \mathrm{~F}=5.496
\end{aligned}
$$

For example, if a team gains 100 more yards during a season, its winning percentage increases by .0156 (i.e., froin .4844 to .5000 ); if it allows 100 more yards, its winnimg percentage falls .0052 . For the statistical significance of each variable, see Thesis, supra note 6 , at 48 . The regression uses all NFL team statistics from the 1983-1984 to 1986-1987 seasons. For the source of the data used, see id. at 93-94. 
changes in a team's aggregate performance statistics froin one year to the next corresponded to the change in that team's winning percentage over the same period. For example, in baseball, the equation described how changes in certain statistics, such as team's ERA, batting average, and stolen bases, affected that team's winning percentage. This equation shows only how aggregate team statistics affect team winning percentage; however, one can calcnlate the effect of an individual player on a team's aggregate statistics by inserting the player's statistics into the team's overall statistics. ${ }^{132}$

The second component of the inodel determines how changes in a team's winning percentage affect a team's overall revenues. ${ }^{133}$ It inust be emphasized that several factors besides winning percentage affect revenues, such as the population of the city and the size of the stadiun in

In baseball, CHWP was run on changes in a team's slugging average ("CHSA"), team earned run average ("CHERA"), stolen bases ("CHSB"), and fielding average ("CHFA"). The following equation resulted:

$$
\begin{aligned}
& \text { CHWP }=-.004+(1.78)(\mathrm{CHSA})-(.107)(\mathrm{CHERA})+(4.427)(\mathrm{CHFA})+(.0003)(\mathrm{CHSB})+ \\
& (.025)(\mathrm{DCONT})-(.003)(\mathrm{DOUT}) \\
& \mathrm{n}=78, \quad \mathrm{R} 2=.79 \quad \mathrm{~F}=45.2
\end{aligned}
$$

For example, a .01 increase in team slugging average increases team winning percentage by .0178 ; a .01 decrease in team ERA increases team winning percentage by .0178 . For the statistical significance of each variable, see id. at 29. The regression uses data for all MLB teams for the 1983 to 1986 seasons. For the source of the data, see id. at 93.

In basketbail, CHWP was run on changes in the team's statistics ("1") and its opposition's statistics against them ("2") in field goal percentage ("CHFG1," "CHFG2"), free throw percentage ("CHFT1," "CHFT2"), rebounds ("CHRBD1," "CHRBD2), turnovers ("TO1," "TO2") and assists ("CHASS1," "CHASS2"). The following equation resulted:

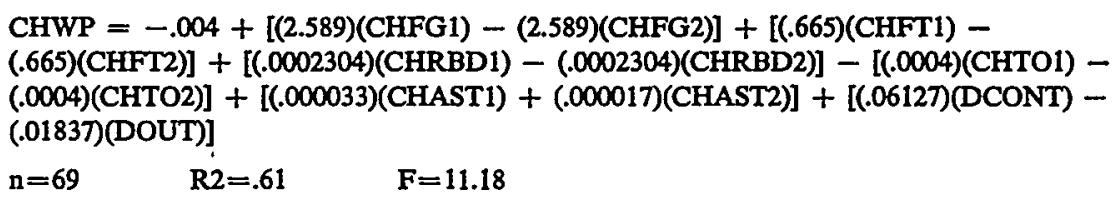

For example, either a .01 increase in a team's field goal percentage or the same decrease in its opponent's field goal percentage increases that team's winning percentage by .0259 . This is a restricted regression in which home team and opposition statistics produce the same, but opposite, effects. The restriction forced the regression to produce identical coefficients for the corresponding offensive and defensive figures (it was run unrestricted initially, and offensive and defensive statistics came so close that the restricted inethod was attempted). The restriction is statistically significant. The opposition's assist statistic carries the wrong sign, but is not statistically significant; however, assists are left unrestricted. For individual statistical significance of each variable, sec $i d$. at 65 . The regression uses data for all teams for the 1983-1984 through 1986-1987 seasons. For the source of the data, see id. at 94.

132. See infra note 144 and accompanying text.

133. The inodel ran separate regressions for each revenue source, instead of lumping all revenues together. Total revenue estimates are subjective. The values used in the model are all objective values. It is very useful to see how winning percentage affects different sources of revenues. The revenue sources considered included hoine and away attendance, concession sales, and local and network radio and television broadcasting payınents. 


\section{which a team plays. Moreover, as mentioned previously, some players}

\section{Attendance}

For each attendance regression, the model analyzes the change in a specific team's revenue over two consecutive seasons ("CHHATT" for home attendance, "CHAWATT" for away attendance) against the specific team's corresponding change in winning percentage ("CHWP") as one variable. The regression also includes a lag change in winning percentage ("LCHWP"). For example, for a team's attendance change between 1987 and 1986, the corresponding LCHWP would be the change in the team's winning percentage between 1986 and 1985 . This variable is necessary because the team's performance im past years influences current attendance figures, especially through season ticket sales. Other variables include changes, corresponding to the team's change in revenues, in the team's city population ("CHSMSA"), stadium capacity ("CHSTAD"), contender statns ("DCONT," "DOUT"), overall fan interest in the sport during the year ("CH85," "CH86"), and whether the team won the championship game in the year preceding the change in attendance. DCONT and DOUT are the same as in the performance regression, supra note 131; attendance should increase if the team is a contender. The championship variable is a lag variable similar to the lag change in winning percentage. For example, if the team wins the World Series one year, attendance should increase the following year. Two variables were used in each sport: 1) The team was the champion in the preceding year, but not in the year before that (baseball = "DLWS," football = "LCHSUP"); 2) The opposite occurs (baseball = "DLNWS," football = "LCHNSUP"). The NBA equation did not include this variable because in the years studied there were only two changes in champions, which would skew the effeet. Another variable measures the change in the number of stars each team had ("CHSTARS") corresponding to the change in attendance. Stars are an important part of the model that recognizes that certain players can increase team revenues other than by helping their team win. For example, many people watch the Chicago Bulls just to watch Michael Jordan, regardless of how the team as a whole performs. Star value is very difficult to measure, in part because certain players would be more popular to certain teams (for example, players who are from the area or went to college in the same city as the professional team). The model tries to use an objective value. To be a "STAR," the player has to play in a certain number of All-Star games, generally thought to reflect a player's performance and popularity. I used soine discretion for young players who were not in the League enough years to qualify. The variable CHSTARS therefore reflected the change in the number of stars that a team had during the years in question.

The regression for home attendance was run on each sport. For baseball, the following equation resulted:

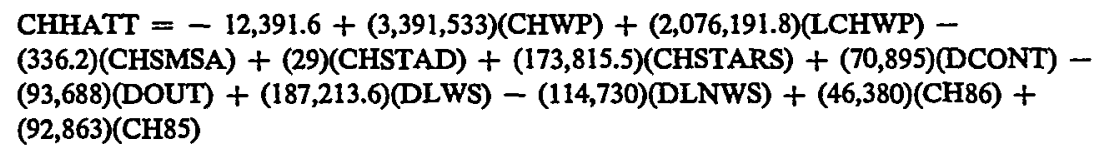

$\mathrm{n}=78 \quad \mathrm{R} 2=.73 \quad \mathrm{~F}=18.53$

For example, a .01 increase in a team's winning percentage that is expected to last over time increases its home attendance by $33,915.533$ and by $20,761.918$ the following year. One then multiphes the change in attendance by the ticket price to see the change on actual revenues. For the statistical significance of the equation, see Thesis, supra note 6, at 32. CHSMSA carries the wrong sign, but is not statistically significant. The regression used data from the 1983 to 1986 seasons. For the source of all data used, see id. at 93.

For basketball, the following equation resulted:

$$
\begin{aligned}
& \text { CHHATT }=16,005.7+(261,496.94)(\text { CHWP })+(89,591.49)(\text { LCHWP })+(14.43)(C H S M S A) \\
& -(13.72)(\text { CHSTAD })+(40,257.9) \text { (CHSTARS) }+(2,080) \text { (DCONT) }-(30,897) \text { (DOUT) }+ \\
& (27,823.3)(\text { CH86) }+(11,149)(\text { CH85) } \\
& n=69 \quad \text { R2 }=.378 \quad \mathrm{~F}=3.977
\end{aligned}
$$

For the equation's statistical significance, see $i d$. at 67 . The regression uses data from the 1983-1984 to 1986-1987 seasons. For the source of data used, see id. at 93. 


\section{generate revenues simply because they are star players. These variables}

The football regression also included the change in the team's opponents winning percentage ("CHHOWP"), since people should prefer to see better teams play. The following equation resulted:

CHHATT $=2,422.76+(134,152.32)($ CHWP $)+(309)($ LCHWP $)-(92.418)($ CHSMSA $)+$

$(4.175)$ (CHSTAD) $+(15,054.43)$ (CHSTARS) $+(36,777.61)$ (CHHOWP) $+(9,555.27)$ (DCONT)

- $(21,141.33)$ (DOUT) $+(61,697)$ (LCHSUP) $+(2,584.32)$ (LCHNSUP) $+(15,077.49)$ (CH86)

- $(1,994.77)$ (CH85)

$\mathrm{n}=84 \quad \mathrm{R} 2=.417 \quad \mathrm{~F}=4.23$

For the equation's statistical significance, see $i d$ at 67 . The regression uses data for the 1983-1984 through 1986-1987 seasons. For the source of data used, see id. at 93-94.

To calculate the effect of winning percentage on revenues, one must multiply the change in attendance by the ticket price. The nodel keeps revenues in 1986 dollars, so the average ticket price for each sport in 1986 is used: $\$ 6.50$ in baseball, $\$ 17.10$ in football, and $\$ 13.40 \mathrm{~m}$ basketball. This number is then inultiplied by the percentage the home team retains.

Although the model assumes that rcal ticket prices remain constant, that assumption is a flaw of the study. If winning increases fan demand for the product, owners may (and often do) increase the real ticket price. When teams do not generally play to stadium capacity the problem is not particularly severe, because the extra demand is met by mcreased attendance. However, if teams generally play to full stadiums, the ouly way the owner can capitalize on the increased demand is to raise real ticket prices.

The regression for away attendance was run only for football and baseball, since the away team in the NBA does not share in revenues. For both sports, the model looks at the change in the away team's stadium size ("CHASTAD"), population ("CHASMSA"), and number of stars ("CHASTARS").

For baseball, the following equation resulted:

CHAWATT $=-134,864+(728,707.3)($ CHWP $)+(664,035.2)($ LCHWP $)+(17.45)$ (CHASTAD) + $(1,712.5)$ (CHASMSA) + $(93,639.6)$ (CHSTARS) + (46,665.9)(CHASTARS) + $(57,573)($ DCONT $)+(2,673)$ (DOUT) $-(14,962.3)$ (DLWS $)-(122,825)$ (DLNWS $)+$ $(14,236.9)(\mathrm{CH} 86)+(67,069.2)$ (CH85)

$\mathrm{n}=78 \quad \mathrm{R} 2=.43 \quad \mathrm{~F}=4.12$

For the equation's statistical significance, see id. at 35. The regression used data for the 1983 through 1986 seasons. For the source of data used, see $i d$. at 93.

For football, the regression also includes a variable for the change in the away team's winning percentage ("CHAWP"). The following equation resulted:

CHAWATT $=6,649.13+(56,071.64)($ CHWP $)+(28,189.19)$ (LCHWP) $+(3.983)$ (CHASMSA $)$

$+(0.9986)$ (CHASTAD) $+(6,270.93)$ (CHSTARS) $+(256,836.67)$ (CHAWP) + $(4,373.62)($ DCONT $)-(6,530)($ DOUT $)+(29,045.81)($ LCHSUP $)+(2,177.3)$ (LCHNSUP $)+$ $(5,385.72)$ (CH86) - $(10,287.94)$ (CH85)

$\mathrm{n}=84 \quad \mathrm{R} 2=.327 \quad \mathrm{~F}=2.874$

For the equation's statistical significance, see id. at 54. The regression used data for the 1983-1984 through 1986-1987 seasons. For the source of data used, see id. at 93.

To calculate the effect winning percentage has on revenues, one must inultiply the change in away attendance by the ticket price. The model keeps revenues in 1986 dollars, so the average ticket price for each sport in 1986 is used: $\$ 6.50$ in baseball and $\$ 17.10$ in football. This number is then inultiplied by the percentage the away team retains.

2. Concession Sales

Proceeds from concession sales are retained entirely by the home team in all the studied sports. Concession sale change is a function of attendance changes. Since no data on concession sales was available, the inodel assumed that concession profits increased by \$1.00/person in 1986 dollars. This 
are controlled for in the inodel. The regression determines how a change in a team's winning percentage, holding these other variables constant, affects each revenue source for that team: home and away attendance revenues; network and local radio and television broadcast revenues; and concession revenues. By aggregating these effects, the inodel calculates the effect of winning percentage on total revenues. The information produced by the two stages of the regression provides a basis for calculating the impact of an individual player on a team's total revenues. ${ }^{134}$

is a $\$ 1.00$ increase in profits, not revenues. Therefore, one gets the effect on concession sales by multiplying the change in home attendance by $\$ 1.00$.

\section{TV and Radio Payments}

The final regression measures how the change in a specific team's local television and radio revenues ("CHREALTV") corresponds to that team's change in winning percentage. The model puts all local broadcast revenues into 1986 dollars, keeping the real dollar value constant. A team's current winning percentage does not affect current broadcast payinents because the sides negotiate the contract prior to a given season. Only past winning affects broadcast revenues. The study uses both a one year lag change ("LCHWP") and a two year lag change ("L2CHWP").

Other variables include the change in population size ("LCHSMSA"), stadium size ("LCHSTAD"), number of stars on the team ("LCHSTARS"), contender status ("DCONT," "DOUT"), and sport popularity ("CH87," "CH86"). The regression uses one year lag changes for these variables because the current change in broadcast revenues does not reflect current changes in these variables.

This regression was run for baseball, but not for the NFL or NBA. No regression was run for football because the NFL does not allow local broadeasts of regular season or playoff games. The NFL allows local broadcasts for pre-season games, but no data were available for such events. No regression could be run for the NBA because data was unavailable; the NBA does not furnish local broadcast information. A 1982 study estimated that local broadcast payinents ranged betwecn $\$ 1$ million and \$5 million. See R. BERRY, supra note 7, at 163.

For baseball, the following equation resulted:

CHREALTV $=172,157+(4,424,817)$ (LCHWP $)-(469,215)($ L2CHWP $)-(621)($ LCHSMSA $)$ $+(249,649)$ (LCHSTARS) $-(249,934)$ (DCONT) $+(549,667)$ (DOUT) $+(87,916)$ (CH87) + $(644,130)(\mathrm{CH} 86)$

$\mathrm{n}=78 \quad \mathrm{R} 2=.21 \quad \mathrm{~F}=2.3$

For the statistieal significance of each variable, see Thesis, supra note 6, at 36. L2CHWP, LCHSMSA, DCONT, and DOUT carry unexpected signs, but are not statistically significant. The regression used data for the 1983 through 1986 seasons. For the source of data used, see id. at 93.

The final piece of the model accounts for network broadcasting payments. Because each league splits network payinents evenly among the teams, it is assumed that one team's individual team performance cannot affect its network revenues. Therefore, the model simply adds its team's share of network revenues to consider the overall effect. Because all figures are in 1986 dollars, the model uses 1986 network contract data. Network payinents totalled $\$ 55$ million $(\$ 2,391,304$ per team) in the NBA, see Basketball '87, BROADCASTING, Oct. 19, 1987, at 48 (for individual contracts); \$181 million ( $\$ 6,960,000$ per team) in MLB (though ESPN's new contract will imcrease this figure), see Baseball '87, Broadcasting, Mar. 2, 1987, at 47 (TV contracts); Baseball '86, BroadcastiNG, Mar. 3, 1986, at 43 (radio contracts); $\$ 2.2$ Million ( $\$ 17,875,000$ per team) in the NFL, see Football 1985, BROADCASTING, Aug. 5, 1985, at 37 (giving lump sun and individual contracts).

134. See infra note 144 and accompanying text. 


\section{Market Structure and Revenue Sources for the NFL, NBA, and $M L B$}

The NFL, NBA, and MLB derive their revenues from various sources. Before calculatimg a player's impact on overall team revenues, it is important to be familiar with the revenue structure in each league. The major sources of revenues for sports franchises include gate receipts, which encompasses ticket and concession sales, and network and local broadcasting payments.

The importance of each revenue source varies among the different sports leagues, in part because attendance levels differ among the sports, and in part because the leagues use different methods of sharing revenues among individual teams. In all three sports, the league sphits the network broadcasting revenues equally among the teams. Local broadcast payments are also treated the same way-the local team keeps the entire payment. ${ }^{135}$ The three leagues use different allocations for ticket receipts. The NFL host club retains sixty percent of gate ticket revenues; the visiting team gets the reinaining forty percent. ${ }^{136}$ In the NBA, the visiting teain does not reeeive any of the ticket receipts; the home team gets ninety-two percent of the revenue and the League gets the remaining eight percent. ${ }^{137}$ MLB's gate-sharing scheme differs between the American and National Leagues. ${ }^{138}$ In the American League, the home team, the visiting team, and the American League retain seventy-seven percent, twenty percent, and three percent of the gate receipts, respectively. ${ }^{139}$ The National League's method is more coinplicated; sharing is not done on a percentage basis, but depends on ticket prices and the number of noshows. ${ }^{140}$

The revenue figures for each league demonstrate the differences in the relative importance of each revenue source for the three leagues. By looking at the average revenue figures for each league for the 1986 sea-

135. Information came from telephone interviews with the offices of the American League of Professional Baseball Clubs, the National Basketball Association Commissioner, and the National Football League Players' Association. See also Sanoff, Once Again, Time Out for the Fans, U.S. NEWS \& WORLD REP., Oct. 5, 1987, at 30.

136. Sanoff, supra note 135 , at 30 . No figure for the amount the NFL retained was found.

137. Telephone interview with the office of the National Basketball Association Commissioner.

138. The model uses the American League version for calculations.

139. Telephone interview with office of the American League of Professional Baseball Clubs.

140. The National League does not share revenues of no-shows (people who purchased tickets but failed to attend the game). Sharing occurs ouly for those who attended the game; the home team gets all no-show revenue. Each person attending the game counts as one unit. The visiting team gets $\$ 0.53$ per umit, the National League gets $\$ 0.29$ per umit, and the home team gets the remaining $\$ 0.29$ per unit. The home team then gets the remaining portion of the tieket price (anything over $\$ 1.00$ per ticket). Telephone interview with the office of the National League of Professional Baseball Clubs. 
son, one can first estimate an average team's revenues, ${ }^{141}$ and then derive the exact make-up of a league's revenues. Table 1 shows the relative importance of each revenue source for the NBA, NFL, and MLB:

TABLE $1^{142}$

Percentage of Total Revenues

\begin{tabular}{|c|c|c|c|}
\hline Revenue Source & Baseball & Football & Basketball \\
\hline Attendance (home \& away) & $45.25 \%$ & $28.73 \%$ & $\begin{array}{c}68.92 \%{ }^{*} \\
(56.81 \%)^{* *}\end{array}$ \\
\hline Concession profits & $6.96 \%$ & $1.28 \%$ & $\begin{array}{c}5.59 \%^{*} \\
(4.61 \%)^{* *}\end{array}$ \\
\hline Local TV and radio & $20.48 \%$ & $3.65 \%$ & $\begin{array}{c}-^{*} \\
(21.00 \%)^{* *}\end{array}$ \\
\hline Network TV and radio & $26.95 \%$ & $65.94 \%$ & $\begin{array}{l}25.49 \%^{*} \\
(17.57 \%)^{* *}\end{array}$ \\
\hline
\end{tabular}

The NBA and MLB generate the bulk of their revenues from sources that are either completely retained by the home team or shared to only a small extent. By comparison, the NFL generates the bulk of its revenues from a source that is completely shared; less than five percent of its revenues derive from a source entirely retained by the home team.

\section{Player Impact on Revenues}

1. Hypothetical Calculations. With the information from the stage 1 and 2 regressions, one can determine an individual player's impact on overall team revenues. This is done by mechamically substituting one player's statistics (i.e., the hypothetical prospective free agent) for the statistics of the player whom he will replace. One must first calculate how this change alters a team's winning percentage, and then see how that change in winning percentage alters revenues. ${ }^{144}$

141. The study used the American League in baseball. The average American League team earned $\$ 25,826,286$; the average NFL team earned $\$ 27,106,419$; and the average NBA team earned $\$ 9,387,912$, excluding local broadcast payments. See Thesis, supra note 6 , at 38, 56, 69 (describing calculations).

142. See id. at 80 .

143. The NBA does not release information about teams' local broadcast contracts.

144. Using the regressions previously described, Table 2 shows how each change in a team's statistic affects winning percentage and revenues (the figures in parentheses show what one player must do to produce that change). 
TABLE 2

Change in

Team Statistic

Change in

Winning

Percentage

Change in

Revenue

Percentage

Revenue

Increase

BASEBALL

Slugging Average:

+.001 (.417 for one player)

$+.010(.498)$

$+.00178$

$+\$ 70,306$

$+0.272 \%$

$+.0178$

$+\$ 703,060$

$+2.72 \%$

$+.00044$

$+\$ 17,379$

$+\$ 173,379$

$+0.067 \%$

$+0.673 \%$

$+.0003$

$+\$ 11,849$

$+0.0459 \%$

$+\$ 236,980$

$+0.918 \%$

+20 (32)

ERA:

-.01 (4.116 for 1 player)

-.10 (3.548)

$+.00107$

$+\$ 42,263$

$+0.164 \%$

$+.01070$

$+\$ 422,263$

$+1.636 \%$

$+.00025$

$+\$ 9,874$

$+0.038 \%$

$+\$ 98,740$

$+0.382 \%$

DCONT (through Rev):

+.01 chance

+.10 chance

DCONT (total effect):

+.01 chance

+.10 chance

$+.00250$

*

$+\$ 1,095 \quad+0.004 \%$

$+\$ 10,950+0.042 \%$

*

$+\$ 10,969+.041 \%$

$+\$ 109,690+.425 \%$

DLWS:

+.01 chance

+.10 chance

*

$+\$ 11,329 \quad+.0439 \%$

$+\$ 110,329+.4387 \%$

STAR (addition of one):

FOOTBALL

Rushing Yards Gained:

$+100$

$+500$

$+.01557$

$+.07785$

$+\$ 32,547$

$+\$ 162,735$

$+.12 \%$

$+.64 \%$

Rushing Yards Allowed:

$-100$

$-500$

$+.00516$

$+\$ 10,786$

$+.04 \%$

$+.02580$

$+\$ 53,931$

$+.20 \%$

Passing Yards Gained:

$+100$

$+500$

$+.0081$

$+.04085$

$+\$ 17,078$

$+\$ 85,392$

$+0.063 \%$

$+0.315 \%$

Passing Yards Allowed:

$-100$

$+.00214$

$+\$ 4,473$

$+\$ 22,367$
$+0.016 \%$

$+0.083 \%$ 
Turnovers Lost:

$-1$

$-10$

Turnovers Recovered:

+1 (unexpected sign)

Home Penalty Yards:

-100 (unexpected sign)

Opposition Penalty Yards:

$-100$

$-500$

Home Field Goal Percentage:

$+.001$

$+.100$

Opposition Field Goal Percentage

$-.001$

$-.100$

DCONT (through WP):

+.01 chance

+.10 chance

DCONT (through Rev.):

+.01 chance

+.10 chance

DCONT (total effect):

+.01 chance

+.10 chance

LCHSUP:

+.01 chance

+.10 chance

CHOPWP (through WP):

$-.001$

$-.010$

$$
+.0006044
$$$$
+.006044
$$

$+.0204$

$+.1020$

$+.003890$

$+.00138$

$+.011380$
$+\$ 2,090$

$+\$ 20,904$

$-.000043 \quad-\$ 90$

$-.0025 \quad-\$ 5,226$

$+\$ 42,643$

$+\$ 213,217$

$+.0000389+\$ 81$

$+\$ 8,131$

$+\$ 690$

$+\$ 68,982$

$+\$ 2,379$

$+\$ 23,790$

$+\$ 1,375$

$+\$ 13,751$

$* \quad+\$ 3,754$

$+\$ 37,541$

* $\quad \$ 8,934$

* $\quad+\$ 89,340$

$+\$ 1,263$

$+\$ 12,630$

* $\quad+\$ 1,757$

$+\$ 17,567$

$+(.5)($ CHOPWP)):

CHAWP (total effect $=$

$+.001$

$+.010$

$+0.0077 \%$

$+0.0771 \%$

$-0.0003 \%$

$-0.019 \%$

$+0.157 \%$

$+0.787 \%$

$+0.0003 \%$

$+0.030 \%$

$+0.0025 \%$

$+0.2500 \%$

$+0.0088 \%$

$+0.0880 \%$

$+0.0051 \%$

$+0.0507 \%$

$+0.0138 \%$

$+0.1385 \%$

Home Opponent's WP (CHHOWP (through Rev.)):
$+.001$
$+.010$
$+\$ 377$
$+\$ 3,773$
Home Opponent's WP (CHHOWP (total effect)):

$\begin{array}{llll}+.001 & * & -\$ 254 & -0.00094 \% \\ +.010 & * & -2,542 & -0.0094 \% \\ \text { STAR (addition of one): } & & & \\ & * & +\$ 212,405 & +0.784 \%\end{array}$
$+0.0014 \%$
$+0.0139 \%$
$-0.00094 \%$
$+0.784 \%$

$+0.033 \%$

$+0.330 \%$

$+0.0047 \%$

$+0.0470 \%$

$+0.0065 \%$

$+0.0648 \%$

$+0.00415 \%$

$+0.0415 \%$ 
BASKETBALL

FG1, FG2:

\begin{tabular}{|c|c|c|c|}
\hline $\begin{array}{l}+.001(.486)-.001 \\
+.010(.540)-.010\end{array}$ & $\begin{array}{l}+.002589 \\
+.025890\end{array}$ & $\begin{array}{l}+\$ 12,115 \\
+\$ 121,148\end{array}$ & $\begin{array}{l}+0.129 \% \\
+1.290 \%\end{array}$ \\
\hline $\begin{array}{l}\text { FT1, FT2: } \\
+.001(.769)-.001 \\
+.010(.823)-.010\end{array}$ & $\begin{array}{l}+.000665 \\
+.006650\end{array}$ & $\begin{array}{l}+\$ 3,112 \\
+\$ 31,118\end{array}$ & $\begin{array}{l}+0.033 \% \\
+0.332 \%\end{array}$ \\
\hline $\begin{array}{l}\text { RBD1, RBD2: } \\
+10(612)-10 \\
+100(702)-100\end{array}$ & $\begin{array}{l}+.002304 \\
+.02304\end{array}$ & $\begin{array}{l}+\$ 10,781 \\
+107,812\end{array}$ & $\begin{array}{l}+0.115 \% \\
+1.150 \%\end{array}$ \\
\hline $\begin{array}{l}\text { TO1, TO2: } \\
-10(222)+10 \\
-100(132)+100\end{array}$ & $\begin{array}{l}+.004 \\
+.040\end{array}$ & $\begin{array}{l}+\$ 18,717 \\
+\$ 187,173\end{array}$ & $\begin{array}{l}+0.199 \% \\
+1.99 \%\end{array}$ \\
\hline $\begin{array}{l}\text { AST1: } \\
+10(363) \\
+100(455)\end{array}$ & $\begin{array}{l}+.00033 \\
+.00330\end{array}$ & $\begin{array}{l}+\$ 1,544 \\
+\$ 15,441\end{array}$ & $\begin{array}{l}+0.016 \% \\
+0.165 \%\end{array}$ \\
\hline $\begin{array}{l}\text { DCONT (through WP): } \\
+.01 \text { chance } \\
+.10 \text { chance }\end{array}$ & $\begin{array}{l}+.0006127 \\
+.0061270\end{array}$ & $\begin{array}{l}+\$ 2,867 \\
+\$ 28,670\end{array}$ & $\begin{array}{l}+0.031 \% \\
+0.306 \%\end{array}$ \\
\hline $\begin{array}{l}\text { DCONT (through Rev.): } \\
+.01 \text { chance } \\
+.10 \text { chance }\end{array}$ & * & $\begin{array}{l}+\$ 277 \\
+\$ 2,772\end{array}$ & $\begin{array}{l}+0.0029 \% \\
+0.0290 \%\end{array}$ \\
\hline $\begin{array}{l}\text { DCONT (total effect): } \\
+.01 \text { chance } \\
+.10 \text { chance }\end{array}$ & * & $\begin{array}{l}+\$ 3,144 \\
+\$ 31,442\end{array}$ & $\begin{array}{l}+0.0335 \% \\
+0.3351 \%\end{array}$ \\
\hline STAR (addition of one): & * & $+\$ 536,557$ & $+5.718 \%$ \\
\hline
\end{tabular}

Two crucial points emerge from the model. First, in all three sports, team statistics affect team performance. Moreover, an individual player inay be able to produce changes in team performance. ${ }^{145}$ However, the effects of winning on overall revenues differ from sport to sport. Winning one additional game in the NFL (WP mcreases by .0625) causes a team's revenues to increase by $\$ 130,046$ (a $0.33 \%$ increase of total revenues), whereas the same mcrease in winning percentage in the NBA (which corresponds to 5.1 gaines) results in a $\$ 292,855$ revenue gain $(3.16 \%$ increase). But the same mcrease in winning percentage in MLB (10.1 games) produces a $\$ 2,463,523$ revenue gain (9.54\% increase). The results demonstrate that winning is far more important im imcreasing revenue im MLB. Winning also produces twice as large a revenue gain in the NBA as in the NFL, and a much greater gain im percentage terms. By

145. For actual examples, see supra note 144. 
comparison, winning provides only a inarginal revenue gain in the NFL, and very little gain in percentage terms. ${ }^{146}$

The inodel also deinonstrates that a star player can significantly affect team revenues in both the NBA and MLB, both in aggregate and percentage terms. ${ }^{147}$ However, a star player has a much less significant effect on revenues for NFL teams, both in absolute and percentage terms.

2. Actual Calculations. The inodel and table 2 can be used to determine how changes in a team's statistics theoretically affect winning percentage and revenues, but a full understanding of the economics of frec agency in the three sports can be attained only by looking at actual player movements. This understanding can be achieved by using the model to analyze a free agent signing by substituting the free agent's statistics for the replaced player's statistics. ${ }^{148}$

The inodel thus explains the following actual situations: 1) Baseball. What was the Cleveland Indians' imcentive in 1986 to sign outfielder Rickey Henderson and to replace Brett Butler? According to the model, Henderson would increase Cleveland's winning percentage by .0343 (5.5 gaines) and generate an additional $\$ 2,879,899$ (an $11.15 \%$ increase) im revenues. ${ }^{149}$ 2) Football. What was the Indianapolis Colts' imcentive to sign running back Eric Dickerson and to replace their average running back? According to the model, Dickerson mcreases the Colts winning percentage by .05116 (.81 gaines) and generates an additional $\$ 394,610$ (a $1.45 \%$ mcrease) im revenues. ${ }^{150}$ ) 3) Basketball. What was the New York Knicks' mcentive im 1987 to sign "Magic" Johnson and to replace guard Gerald Wilkins? According to the model, Magic increases New York's

146. See supra note 133 .

147. The aggregate effect is larger in MLB, but the percentage effect is about the same in the two sports. See id.

148. An owner bases his economic expectations and his offer on the assumption that the player will perform at the same level he has in the past (the model bases performance on the player's average statistics for the past two seasons). Whether a player actually performs to the owner's expectations is irrelevant to the owner's initial offer. Expectations govern: If the acquired player performs poorly, the owner still has the same financial incentive to sign a similar player. Owners sign players with expectations that certain players will produce added revenues in addition to increasing the team's winning percentage. These expectations include becoming a playof contender or acquiring a star player, both of which have positive effects on revenues.

149. This figure assumes that Cleveland believes that the acquisition of Henderson inproves their contender chances by $20 \%$ and World Series chances by $5 \%$, and that Henderson is a STAR player. Both of these assumptions make Henderson generate revenues in addition to his statistical impact on winning percentage.

150. This figure assumes that Indianapolis beheves that the acquisition of Dickerson improves their contender chances by $10 \%$, their Super Bowl chances by seven percent, and that Dickerson is a STAR player. Both of these assumptions make Dickerson generate revenues in addition to his statistical impact on winning percentage. 
winning percentage by .1073 and generates an additional $\$ 1,041,326$ (an $11.10 \%$ increase) in revenues. ${ }^{151}$

By looking at similar examples, 152 the model deinonstrates that players have the highest impact on winning in the NBA, with players in the NFL and MLB having lesser, but still significant, effects on winning, and that winning has the greatest impact on revenues in both absolute and percentage terms in MLB. In absolute terms, winning is inore than twice as important for revenues in the NBA as it is in the NFL, but much more significant in percentage terms. By contrast, winning has a minor impact on revenues in the NFL. Consequently, one player can significantly affect team revenues in both the NBA and MLB, but can have only a limited impact in the NFL.

\section{E. The Relationship Between Player Performance, Team Performance, Team Revenues, and Free Agency}

The relationships between player performance and team performance, and team performance and team revenues, predict the attitude that both players and owners adopt regarding free agency. ${ }^{153}$ Assuming that players and owners behave rationally, the inodel explaims whether they should or should not support unrestricted free agency, as illustrated by the following scenarios.

First, if an individual can significantly affect team performance, and team performance affects team revenues, the league would einploy unrestricted free agency. Players would deinand unrestricted free agency because they would know that they influence revenues. Owners would not oppose unrestricted free agency because signing free agents would generate revenues.

Second, if an individual affects team performance, but performance does not affect team revenues, a great deal of conflict over free agency would arise. If owners were only concerned with money and acted rationally, they would not sign free agents, because the improved performance of the team would not lead to greater revenues. However, soine owners imight want to win for prestige. Additionally, owners might erroneously believe that winning did in fact yield enhanced revenues. As a result, they would bid irrationally for players. In such a case, restrictions on frec agency would inake econoimic sense froin the owners' standpoint as a curb on their irrationality. Restrictions, such as high compensation

151. This figure assumes that New York believes that the acquisition of Magic improves their contender chances by $10 \%$, and that Magic is a STAR player. Both of these assumptions make Magic generate revenues in addition to his statistical impaet on winning percentage.

152. See Thesis, supra note 6 , at $40-45,59-61,71-75$ (giving examples in the three sports).

153. These are original predictions and were part of iny Thesis, supra note 6. 
costs, would make it costly for owners to bid for players and decrease the temptation to sign free agents. Players, on the other hand, would want to capitalize on owner irrationality and thus would demand unrestricted free agency.

Third, if a star player has no effect on team performance, but personally affects team revenues, teams would have great imcentive to sign that player, and the more effective an unrestricted free agency system would be. As mentioned previously, star players have significant effects on revenues in the NBA and MLB, but a much smaller effect in the NFL.

Fourth, if an individual does not affect team performance, but team performance affects team revenues, the league would not use the free agent system. Owners would look elsewhere to generate revenues.

Fifth, if an individual has no impact on team performance and performance has no impact on team revenues, the league would not use the free agent systein. Owners would have no incentive to sign free agents because they generate neither additional wins nor additional money.

Although these categories are absolute, it is clear that each sport falls soinewhere along the continuum and not wholly imto one of the five categories. Nevertheless, in general terms, the NBA and MLB secm to fall into the first category: Players significantly affect winning percentage and winning percentage significantly affects team revenues. Therefore, these two sports should be conducive to free agency. Currently, both of these sports have less restrictive free agency systems than does the NFL. ${ }^{154}$ The NFL seems to fall into the second category: Players significantly affect team performance, but team performance does not significantly affect team revenues. Therefore, it is not surprising that there should be a great deal of conflict over free agency restrictions in the NFL. This analysis suggests that certain restrictions can eliminate the irrationality of NFL owners.

\section{F. The Relationship Between Revenue Structure and Winning Percentage}

The economic importance of winning will change if the revenue structure of the league changes. If a leagne changes its structure so that all teams share revenues more eveuly, or if network contracts (which are evenly distributed) comprise a significantly greater percentage of revenues, winning will have a smaller financial impact on teams. On the other hand, winning will have a greater impact on revenues if teains stop sharing their revenues or if local broadcast payments are of greater im1-

154. See supra text accompanying notes 60-66. 
portance to the financial welfare of a team. Courts must be aware that changes in the structure of a league will produce these effects. However, for purposes of analyzing the antitrust implications of the free agency restrictions now in effect in the NFL, the results produced by the model are relevant. Courts must understand the incentives that both owners and players have for free agency, the econouric value of players, and how the econoimics of a sports league work.

\section{Judicial Reasoning about the Impact of Free Agency RESTRICTIONS ON COMPETITION}

Based on the model's description of each sports league's economics, it is possible to evaluate the impact that free agency restrictions have on each of the three relevant areas of competition for Section 1 purposesthe labor market, consumer welfare, and the product market.

\section{A. Effect of Free Agency Restrictions on the Labor Market}

Free agency restrictions will affect two areas of the labor market for professional athletes: Player mobility and player salaries. Courts should consider both of these areas when evaluating the reasonableness of free agency restrictions.

1. Effect on Player Mobility. Courts should consider the impact that free agency restrictions have on the players themselves. According to the model, the contested restrictions in the NFL inhibit player movement in the short run, but their impact on player movement will abate in the long run, as owners become more rational about signing free agents. Given unrestricted free agency, many irrational NFL owners would bid for players in the short run. ${ }^{15 s}$ Such owners are irrational, because they want to win, but do not realize that the newly sigued player, while helping the team win more games, probably will not produce revenues equivalent to his higher salary. ${ }^{156}$ Such irrationality would lead to increased player movement in the short run.

In the long run, however, owners should realize that individual players, although possibly increasing the team's winning percentage, are not producing revenues equal to their salaries; the team takes a financial loss on them. The newly rational owners would stop signing these players at such high frequency and player movement would markedly decline. It is assumed that the NFL owners will conform to rational behavior once they start to see the losses in their wallets. Some slight

155. See supra text accompanying notes $144-47$.

156. See id. 
player movement would continue in the long run, howeyer, because winning does affect revenues to a small extent, and star players also affect revenues to a small extent. ${ }^{157}$

Restrictions on free agency may negate the owners' short-term irrationality. Certain restrictions impose visible additional costs on teams signing free agents. For example, requiring the team signing a free agent to give some sort of coinpensation to the team losing the free agent drives up the cost of signing frec agents. As a result, NFL owners are less inclined to sign free agents even in the short run, inhibiting player moveinent to soine extent. Overall, however, restrictions on free agency only decrease short term player inovement; in the long run, even in a system of unrestricted frec agency, player inoveinent would decrease simply because signing individual players does not greatly enhance owners' revenues.

In contrast to the NFL, less restricted free agency should and did increase player mobility in the NBA and MLB in the long run. ${ }^{158}$ In baseball and basketball, the model showed that players affect both team winning percentage and team revenues. ${ }^{159}$ Whether the owners act in accordanee with econo1mic rationality in the short run, significant player moveinent would occur, because the acquisition of players also mcreases a team's winning percentage. If owners look to financial considerations, they would realize that acquiring key players contributes to revenues. Unlike the NFL, however, player moveinent in the NBA and MLB would not halt in the long run, because additional players can generate additional revenues, which can offset the increased salary costs. The players simply recover what they are worth to the team and no loss ensues. Therefore, owners will continue to sign new players for financial reasons. In conclusion, identical free agency restrictions in basketball, baseball, and football would curtail player movennent inore in the NBA and MLB than in the NFL.

The Rule of Reason analysis indicates that particular characteristics of an industry inust be evaluated for Sherman Act purposes. ${ }^{160}$ The preceding discussion indicates that distinctions among the three sports should be relevant for Sherman Act purposes, because the impact of a restriction is determined by the particular characteristics of the sport. Courts have been slow to recognize the importance of the NFL's eco-

157. The fact that so many unprotected NFL players switched teams under the NFL's Plan B, see supra text accompanying note 57, although seeningly contrary to the low movement theory presented, has several explanations.

158. See supra notes $60-66$ and accompanying text.

159. See supra note 144 and accompanying text.

160. See supra notes $78-130$ and accompanying text. 
nomic structure. The Mackey court invalidated the Rozelle Rule, which imposed significant costs for teams signing free agents, ${ }^{161}$ in part because it deterred player inobility; ${ }^{162}$ the court never realized, however, that the rule's impact on player inovement was different in the short run than in the long run. The restriction's effect on player inobility was smaller than the court believed. Moreover, in the imitial stages of Powell v. NFL, Judge Doty demed a inotion for a preliminary mjunction preventing the owners froin continuing to impose restraints on player inovement, stating that the "migration of many key players [with unrestricted free agency] ... could have a devastating, long-term impact on the competitive balance within the league."163 This statement assumes that free agency restrictions increase player movement in the long run, an indication that the court was misconstruing economic reality. Courts today should fully evaluate the long term impact of free agency restrictions, since the anticoinpetitive effect on player inovement may not be as great in the long term as in the short term.

Courts should also recognize that free agency restrictions that reduce owner irrationality have procompetitive effects in several areas. There are two possible objections to the use of a decrease im owner irrationality as a justification for a restraint under of Section 1 of the SherInan Act; both arguments, however, fail. First, one may argue that if the NFL has enough foresight to impose a rule that eliminates the effects of owner irrationality, the NFL owners should be smart enough not to bid for players in the short run even witl unrestricted free agency. Consequently, the free agency restriction would be unnecessary. The flaw in this argument is that an NFL measure, such as a free agency restriction, need not be approved unanimously to produce its binding effect. The rule is binding as long as either a nnajority of the owners enact the rule or the owners and the NFLPA put the rule in a bargaining agreement. Therefore, as long as a majority of owners realize that it is irrational to bid for frec agents, they can bind owners who would otherwise bid wildly for free agents in an unrestricted system (the irrational owners), forcing their comphance with the restriction and making them conform to rational behavior. However, if no free agency restriction exists, the minority irrational owners will contimue to act irrationally. Ouly costly experience will drive these owners to stop bidding for free agents. Conse-

161. See supra note 37 and accompanying text (describing Rozelle Rule).

162. The court stated that "absent the Rozelle Rule, there would be increased movement in interstate commerce of players from one club to another." Mackey v. NFL, 543 F.2d 606, 620 (8th Cir. 1976).

163. Powell v. NFL, 690 F. Supp. 812,818 (D. Minn. 1988). 
quently, free agency restrictions are necessary to combat owner irrationality.

Second, and more significantly, one may debate whether a rule that protects owners from their own irrationality is reasonable for Section 1 purposes. Using a decrease in owner irrationality as a justification for purposes of Section 1 of the Sherman Act is admittedly a controversial finding of this Note, and commentators in the antitrust field may argue against its reasonableness. This Note, however, takes the position that curtailing owner irrationality is indeed reasonable for Section 1 purposes.

Those who would argue that curtailing owner irrationality is not reasonable for Seetion 1 purposes can look to National Society of Professional Engineers v. United States ${ }^{164}$ for support. In Professional Engineers, the Court held that a rule that prohibited competitive bidding among an engineering society's members violated Section 1 of the Sherinan Act. ${ }^{165}$ The rule was designed to prohibit engineers from irrationally offering lower-priced services of lower quality that were potentially dangerous. Professional Engineers does not, however, rule out the possibility that reducing owner irrationality in the NFL is reasonable for Seetion 1 purposes. First, the irrationality is not the same in the two cases. NFL owners are irrational because they fail to realize that high-priced free agents will not actually imcrease team revenues. The engineers were irrational-if at all-by failing to realize that they can turn a high profit without cutting services and quality. A better interpretation is that an engineer's decision to offer lower-priced and lower-quality services is not irrational, but a conscious decision about the way the engineer chooses to conduct busmess.

Second, sports leagues, which require conscious cooperation among league inembers, are a completely different breed than the engineering industry. Engineers can produce their services without the cooperation of other engineers, but sports teams cannot produce their product without other sports teains. Professional Engineers is therefore distinginshable, and the issue of whether a rule is reasonable that hinders owner irrationality in circumstances where cooperation is inherently required is quite novel.

Finally, this Note does not argue that the benefits and profits that go to the owners froin curtailing their irrationality are reasonable for Section 1 purposes. The owners will profit by stifling their irrationality, but this profit is not factored into the Rule of Reason analysis. Whether a restraint prevents owner irrationality or some other inefficiency should

164. 435 U.S. 679 (1978).

165. Id. at 696. 
be of little significance. Ratlier, this Note takes the position that the impact of the decrease in owner irrationality slould be objectively balanced against its effect on the labor market, consumer welfare, and the product market.

It must be emphasized that the Note has relevance for analyzing free agency restrictions under Section 1 even for those who disagree with the assumption that a rule that protects owners from their own irrationality is reasonable for Section 1 purposes. First, it is still necessary to understand how various sports leagues operate in economic terms. The statistical model achieves this result. Second, the model allows one to understand the effects that free agency restrictions have on the labor market, the league as a product, and consumer welfare. Whether or not one accepts the argument that curtailing owner irrationality is reasonable for Section 1 purposes, certain free agency restrictions do produce this effect. An understanding of this effect is necessary for a full understanding of the market. Finally, one can use the model and the findings of this Note to determine the reasonableness of a restriction, and can then exclude the effeets produced by curtailing owner irrationality from the balancing equation.

2. Effect on Player Salaries. In each professional sport, players fighting against free agency restrictions have argued that the restraints depress their salaries. The Mackey court agreed, finding that the Rozelle Rule reduced the salaries paid to NFL players. ${ }^{166}$ This argument lacks significant inerit, given the economics of the NFL. The Eighth Circuit in Mackey failed to distinguish between the three major sports leagues and to analyze each sport's individual market structure. ${ }^{167}$

In the NFL, removal of free agency restrictions would not cause a significant rise in player salaries. As shown by the model, there is little correlation between winning and revenues in the NFL. ${ }^{168}$ As previously discussed, unrestricted free agency would give NFL owners an incentive to sign free agents in the short run. ${ }^{169}$ The increased demand for players would cause player salaries to rise. In the long run, however, owners

166. The court stated that because of the Rozelle Rule, "salaries paid by each club are lower than if competitive bidding were allowed to prevail." Mackey v. NFL, 543 F.2d 606, 620 (8th Cir. 1976).

167. Commentators also frequently ignore the economic distinctions among the sports and advocate uniform restrictions for each sport. See Glassen, supra note 23, at 387-90 (arguing that baseball should be brought in line with other professional sports by revoking their antitrust exemption, since the exemption is economically mefficient and mequitable to baseball players); Note, Less Restrictive Alternatives for Achieving and Maintaining Competitive Balance in Professional Sports, 30 ARIz. L. REV. 889, 904-07 (1988) (recommends same less restrictive model for all three sports).

168. See supra notes $144-46$ and accompanying text.

169. See supra note 148 and accompanying text. 
would stop signing free agents at such high frequency because these players are not producing revenues commensurate with their high salaries. Consequently, salaries would stop increasing due to the decreased demand for player services. Therefore, in the absence of free agency restrictions, the ouly significant increase in player salaries occurs in the short run, the result of owner irrationality. The players are nevertheless likely to achieve soine long term salary gain with unrestricted free agency, because wages are "sticky"-despite downward market forces, it is difficult to achieve salary cuts. Some long term salary gain will also result, because both winning and star players have shight impacts on revenues.

Salaries would also be affected by a team's decreased short-term profitability. Assuming that the irrational short-term increase in salaries resulting froin reinoving free agency restrictions in the NFL would reduce NFL owners' profits, NFL owners would have an incentive to pass on higher salary costs to consumers, through higher-priced broadcast contracts, ticket prices, concession prices, or decreases in stadium quality. If the owners pass on the costs to any of these sources, the competitiveness of the NFL against other sports and entertainment products will decrease. Decreased deinand for the NFL product will eventually reduce player salaries, because once the owners are unable to pass on the higher salary costs to these sources, they will then try to decrease directly player salaries. In either case, the costs associated with free agency mean that the potential for small increases in player salaries caused by reinoving the restrictions is at the very least uncertain, and certainly much less significant, than generally believed. The ultimate effect of the removal of free agency restrictions im the NFL on player salaries is difficult to ascertain; it is clear, liowever, that the courts have exaggerated its likely effect.

In contrast to the NFL, removal of free agency restrictions in the NBA and MLB would increase player salaries even in the long term. This result follows from the model's finding that one player can significantly affect team revenues. 170 Because NBA and MLB players can sig-

170. See supra notes $144-47$ and accompanying text. For example, if one player generates an additional $\$ 100,000$ to a team, that team should be willing to pay an amount less than $\$ 100,000$ to sign that player. However, restrictions such as compensation impose additional costs. If the team must give up a draft choice to sign that same player, the team will only be willing to pay that player an amount less than $\$ 100,000$. The following table shows the rise in player salaries after basketball and baseball moved to more lenient free agency systems (real salary in 1967 dollars in parentheses):

\begin{tabular}{lrlr} 
Year & \multicolumn{2}{c}{ Average MLB salary } & Average NBA salary \\
1972 & $\$ 34,092$ & $(\$ 27,208)$ & $\$ 90,000$ \\
1977 & $\$ 76,066$ & $(\$ 41,910)$ & $\$ 143,000$ \\
1980 & $\$ 143,756$ & $(\$ 58,248)$ & $\$ 189,000$ \\
1984 & $\$ 329,408$ & $(\$ 105,885)$ & $\$ 340,000$
\end{tabular}

Major League Baseball Players' Association; P. StAudohar, supra note 7, at 29, 100. 
nificantly affect team revenues, owners have rational short and long term incentives to sign players for higher salaries. Thus, free agency restrictions that impose costs on teams signing free agents in these two sports will decrease player salaries. Furthermore, in the absence of free agency restrictions, the short term increase in player salaries is not irrational (as it is in the NFL). Therefore, without free agency restrictions, salaries of NBA and MLB players will not decrease from the passing on of costs that is likely to occur in the NFL.

Free agency restrictions are likely to decrease player salaries in the NFL to soine extent, albeit inuch less than identical restrictions in either baseball or basketball. The same is also true of the impact of free agency restrictions on player movement in the three sports. Therefore, if considering the restrictions' impact only on the labor market, the restrictions can be considered anticompetitive (though not as anticompetitive as courts inay have thought). Other possible justifications exist for the use of soine restrictions. These justifications include maintaining team continuity (sincc fans become loyal to players), inaintaining coinpetitive balance in the leagne, otherwise furthering the competitiveness of the NFL agaimst other entertainment products, and benefitting the consumer by providing a quality product at a reasonable price. If a restraint is justified for these reasons, the relatively small decrease in NFL player salaries and player inoveinent caused by certain free agency restrictions should not inake the restriction unreasonable for Section 1 purposes. In the next two sections, the model will be used to determine the economic impact of free agency restrictions in these other areas, thereby coinpleting the antitrust analysis.

\section{B. Impact on Consumer Welfare}

In evaluating free agency restrictions under Section 1 of the Sherman Act, courts have not considered the impact such restrictions have on consumer welfare. In the NFL, certain free agency restrictions benefit the consumer. As previously described, in the absence of free agency restrictions, short tern player moveinent and salary escalation occur because of owner irrationality. ${ }^{171}$ The irrationality results froin the model's finding that players affect team winning percentage, but not teain revenues. ${ }^{172}$ In the short tern, since the increase in player salaries is not inatched by an increase in revenues, owners' profits fall. Without certain free agency restrictions, soine NFL franchises could potentially lose so much money to short run irrationality that the team would fold.

171. See supra notes $144-48$ and accompanying text.

172. See id. 
Although owners are clearly worse off under such a scenario, the more significant result is that consumer choice is reduced. Loss of NFL franchises, however, remains unlikely. ${ }^{173}$

A more probable result of unrestricted free agency restrictions is that teams would suffer decreased profits or even losses in the short run due to owner irrationality. ${ }^{174}$ During the short run, the NFL owners must pass on the artificially high operating expenses (salaries) to other sources, and may pass on the costs directly to consumers im the form of artificially high ticket prices. ${ }^{175}$ If the team is reluctant to charge higher ticket prices, it will pass on its costs to the consumer im another form, such as through a deterioration in stadium quality or security, or through higher concession prices. The owners also may pass on these costs to television and radio producers by demanding more lucrative contracts. In turn, the broadcast coinpanies must charge higher advertising prices; escalated advertising costs are then passed on by the advertiser to the consumer in the form of higher prices for the advertised product. The result is the sanie: The consumer bears the burden of the short-term salary rise. The higher prices created by higher salaries obviously run counter to consumer welfare. Of course, consumers are free to stop "purchasing" NFL football if prices increase, but this is not likely. Therefore, free agency restrictions that impose costs on teams signing free agents and curtail the owners' use of the free agency systein are procoinpetitive under the consumer welfare analysis.

The extent to which the consumer is harmed by the removal of restrictions that impose costs on the use of free agency in the NFL depends on the severity of the owners' irrationality under a systein of unrestricted free agency. The greater the irrationality of the owners, the greater the procoinpetitive benefits of the free agency restrictions. The likely result is that a spree of free agent signings will be a short run phenounenon. However, the consumers lose more than the artificially high prices for even that short run period. A lag effect is sure to result where owners will continue to charge somewhat higher prices to recover previous losses.

The argument that higher prices produced by owner irrationality run counter to consumer welfare analysis bears careful consideration. By

173. Even teams in the smallest markets are unlikely to fold because of their large network contracts and the NFL's revenue sharing schene.

174. See supra notes $144-48$ and accompanying text. This potential is demonstrated by the behavior with Plan B (frequent player movement); however, the financial losses to the owners under this plan are not so large because the better players are still restricted.

175. The players' salaries are artificially high because the players do not generate revenues equal to their salaries. They are not paid what they should be paid, so the ticket prices are also higher than they should be. 
no means do all increases in prices to consumers run counter to consumer welfare. Natural imcreases in the costs of a business, such as investment in research or advertisement, an increase in demand for labor that causes increased wages and higher prices, or increased demand for a product in general, do not weigh against the consumer welfare analysis. Moreover, a busmess cannot conspire with another business to decrease wages below the market level with the justification that it would result in lower prices to consumers. Increases in prices caused by the removal of the free agency restriction are not natural; they result from an ineffciency - the irrationality of the owners. In a perfect world, with perfect information, this mefficiency would not occur. Considered in this hight, certain restrictions in the NFL move a step closer to the perfect world situation and are thus procompetitive. As discussed above, it is irrelevant that the gains stem from preventing owner irrationality as opposed to another source.

Similar free agency restrictions in the NBA and MLB do not produce similar procompetitive effects on consumer welfare. The different results occur because owners im the NBA and MLB are not irrational when they sign free agents. The model demonstrates that players in both the NBA and MLB significantly affect team revenues and are capable of generating revenues commensurate with their increased salaries. Therefore, as demonstrated above, owners in the NBA and MLB, in sharp contrast to NFL owners, do not suffer these irrational short-run losses when unrestricted free agency exists. The higher ticket prices, higher advertising costs, or lower stadium quality that could result from unrestricted free agency in the NFL would not exist in either the NBA or MLB. This analysis illustrates that the saine justifications that exist for free agency restrictions in the NFL-curbing the market inefficiency of owner irrationality-do not exist in either the NBA or MLB.

\section{Effect of Free Agency Restrictions on the Product Market}

Courts should consider two aspects of the NFL's product market when evaluating the reasonableness of free agency restrictions: Intraleague competition, and competition between sports and other forms of entertainment.

1. Intraleague Competition. In the past, courts have viewed the goal of fostering intraleagne competition as a justification for free agency restrictions. ${ }^{176}$ Some degree of intraleague competition is necessary for a

176. Powell v. NFL, 690 F. Supp 812, 816 (D. Minn. 1988); Robertson v. NBA, 389 F. Supp. 867, 892 (S.D.N.Y. 1975). 
league to function because the league as a product suffers if certain teams always win, while others always lose. However, use of the model, coupled with a comparison between the NFL's and MLB's free agency systems, indicates that free agency restrictions will not proinote intraleague competition; therefore, courts should not use this claimed effeet as a justification for the restraint.

Although both Mackey v. NFL ${ }^{177}$ and Robertson v. NBA ${ }^{178}$ struck down free agency restrictions as Section 1 violations, the courts in those cases were reluctant to condemn all restrictions on free agency because they beheved that the successful operation of the league required intraleague balance. ${ }^{179}$ Unrestricted free agency was thought to destroy intraleague balance because it would permit the team owners with the inost money and teams playing in the largest inarkets (for example, the New York City teams) to sign the best players by outbidding poorer teams that play in smaller markets. Simply put, the rich would get better, the poor would get worse. Thus, the courts believed that restrictions on free agency would promote intraleague balanee by decreasing the use of the free agency system and decreasing player novement.

The courts' view is erroneous in hight of baseball's experience with a lemient free agency system. The frequent inovement of players in baseball that has occurred since MLB shifted to its lenient free agency system has not hurt intraleague competition in either the short or long run, as demonstrated by the increased clianges in division wimners. ${ }^{180}$ The expe-

177. 543 F.2d 606 (8th Cir. 1976).

178. 389 F. Supp. 867 (S.D.N.Y. 1975). The Robertson court indicated that it thought the reserve rule was a per se violation of Section 1: The "perpetual reserve system [is] readily susceptible to condemnation .... [It is] analogous to [a] price-fixing device[ condemned as per se violative of the Sherman Act, for ... a perpetual reserve system allow[s] competing teams to eliminate competition in the hiring of players and invariably lower[s] the cost of doing busimess ...." Id. at 893. However, although the court stated that "a perpetual reserve system would ... appear to be a per se violation of the [Sherman Act]," the court declined to rule on the legality of the systein prior to a trial on the merits. Id. at 896. Immediately after the ruling, a settlement was reached and the two sides formulated a collective bargaining agreement that eliminated the reserve rule.

179. The Robertson court stated:

Some degree of economic cooperation which is inherently anti-competitive may well be essential for the survival of ostensibly competitive professional sports leagues. Without these mechanisms unrestrained price wars for the service of the most proficient players will ensue, or so runs the argument, with the wealthiest teams capturing the top talent and the poorer teams facing demise due to the loss of fans and profit.

Id. at 892 (citation omitted). The Mackey court stated:

We note that our disposition of the antitrust issue does not mean that every restraint on competition for players' services would necessarily violate the antitrust laws. ... It may be that soine reasonable restrictions relating to player transfers are necessary for the successful operation of the NFL.

Mackey, 543 F.2d at 623.

180. No single team has dominated baseball since the inception of free agency. With the exception of the Oakland A's, no team won their division in consecutive seasons during the 1980s. 
rience of MLB does not suggest that the same results will occur in football, since the two sports have different market structures. Nevertheless, the statistical model, which shows that players have a much sinaller impact on revenues in the NFL than in MLB, indicates that there will not be a decline in intraleague competition in the NFL with unrestricted free agency. The effect of an unrestricted free agency system on intraleague competition is ultimately determined by owners' economic incentives to sign frce agents. Where the acquisition of players enhances revenues, owners are more willing to sign free agents, and more player moveinent occurs. Increased player movement potentially decreases intraleague competition because the better players will sign with the richest teams.

In the short run, some player movement will occur with unrestricted free agency im the NFL because of owner irrationality. However, there is no reason to beheve that this movement would be any greater than has occurred in baseball. Since the move to a lenient free agency systen did not hurt intraleague competition in baseball, it is unlikely that unrestricted free agency would impair intraleague competition in the NFL, either in the short or long run.

Though the Robertson court relied on an erroneous notion about intraleague competition, its reluctance to ban all free agency in the NBA was nevertheless more economically justified than the Eighth Circuit's reluctance to do so in Mackey. The model shows that an NBA player has a greater impact on winning than a baseball player, so that movement of key players will hinder league parity more than in baseball. However, winning affects revenues less in the NBA than in baseball, which makes the owners' incentive to sign players less in the NBA than in MLB. In baseball and basketball, the cuniulative effect of one player on revenues is relatively close, implying that unrestricted free agency will not hurt intraleague competition more in the NBA than in MLB. Therefore, im all three sports, free agency restrictions will not improve the coinpetitiveness of the leagues by enhancing intraleague competition.

2. Competition With Other Entertainment. The irrational short term inflation of player salaries that occurs in the absence of free agency restrictions in the NFL has the potential to decrease the competitiveness of the NFL as a product. Owners may pass on the costs of artificially inflated salaries to consumers in the form of higher ticket prices, broadcast contracts, or concession prices. In this event, the conipetitiveness of the League as a product will decline to the extent that other forms of entertainment can substitute for the NFL. ${ }^{181}$ Although one may argue

181. This effect depends on the cross-elasticity of demand between the NFL and other products. 
that people will still watch football on television despite higher ticket and concession prices, the demand for attendance at games certainly falls. Moreover, when people stop going to the games, total demand for the NFL as a product falls, because people will lose at least some interest in the sport. If the owners pass on the costs only via higher broadcast contracts, NFL competitiveness may also fall, although it is less likely. Although it remains unlikely that the network broadcasters will televise fewer NFL games due to the higher contract demands, it is possible that smaller networks, such as ESPN and TNT, will televise fewer games. In this way, free agency restrictions that limit owner irrationality improve the competitiveness of the NFL against other products.

Were the NBA and MLB to adopt free agency restrictions similar to the NFL's, the restrictions wonld not produce the same procompetitive effects on those leagues as products, for the same reason that the restrictions would not produce the same consumer welfare benefits: With unrestricted free agency, neither the NBA nor MLB encounters artificially inflated salaries. Therefore, free agency restrictions in these two sports are not needed to prevent owners from passing on the costs of inflated salaries to other sources.

Free agency restrictions also may improve the competitiveness of a league as a product if the restrictions promote team continuity. Although it is impossible to measure the degree to which fans value team continuity, it is likely that fans identify with players. Therefore, the competitiveness of a league's product should improve as team contimuity improves. In the NFL, it was previously demonstrated that, in the absence of free agency restrictions, player movement will increase in the short term, but stabilize in the long term. ${ }^{182}$ Free agency restrictions that limit this movement thus imcrease team contmuity in the short term; however, the restrictions improve team continuity to a much smaller extent in the long run. Therefore, through team continuity, certain restrictions may improve the competitiveness of the NFL as a product.

By contrast, certain free agency restrictions have a much greater effect on team continuity in the NBA and MLB than in the NFL. The model's finding that players im the NBA and MLB significantly affect team revenues, and that player movement contimues in the long run, provides the basis for this resnlt. Therefore, free agency restrictions that impose costs on teams signing free agents increase team continuity in the NBA and MLB and potentially imcrease team revenues. This Note does not purport to calculate the impact that team continuity has on product competitiveness. However, to the extent that a positive correlation ex- 
ists, the procompetitive effects of identical free agency restrictions attributable to team continuity are much greater in the NBA and MLB than in the NFL.

The final factor that courts have failed to address in their Section 1 analysis is the extent to which football competes against other forms of entertainment. This factor is relevant if there is high substitutability among forms of entertainment; if so, small changes in the appcal of one product, NFL football for example, can cause fans to switch to other forms of entertainment. As a result, small increases in ticket prices, decreases in overall NFL quality, decreases in intraleague competitiveness, or imcreases in player turnover (which may influence fan loyalty to a team) will cause a significant decline in the competitiveness of the NFL as a product. On the other hand, if demand for NFL is inelastic, the four changes histed above will not significantly decrease the NFL's competitiveness agaimst other products. The procompetitive effect of free agency restrictions that curtail changes in the NFL's product thus depends on whether NFL football is readily interchangeable with other products. ${ }^{183}$

One commentator has suggested that courts analyzing Section 2 violations have failed to consider how coinpetition among sports leagues has changed. ${ }^{184}$ This claim is equally applicable to Section 1 violations. ${ }^{185}$ Competition among leagues is not static, ${ }^{186}$ and courts inust account for the differences in such competition at any given time. The NFL season begins as the baseball pennant races are lieating up; its regular season then coincides with the first half of the NBA and National Hockey League (NHL) schedules. The NBA season also coincides with the NHL. Although baseball ends as the NFL starts, no sports league plays during the bulk of the baseball season. College sports also compete agaimst professional sports. The NFL and NBA receive great coinpetition froin their college counterparts, whereas MLB faces much less com-

183. Commentators suggest that the demand for football is inelastic because stadiums are almost always filled to capacity. See Lock, The Scope of the Labor Exemption In Professional Sports, 1989 DUKE L.J. 339, 357.

184. Rosenbaum, supra note 27, at 785 n.238. The issue has often been presented in Section 2 cases. See Los Angeles Memorial Coliseum Comm'n v. NFL, 726 F.2d 1381, 1393 (9th Cir. 1984) ("NFL football has limited substitutes from a consumer standpoint .... NFL football has a different set of fans than college football."); Lazaroff, The Antitrust Implications of Franchise Relocation Restrictions in Professional Sports, 53 FordhaM L. REV. 157, 209 (1984) ("Both fans and stadium operators view NFL football as a unique and separate product.").

185. These considerations are relevant whether one adopts the labor side approach, product side approach, or consumer effect analysis.

186. See Rosenbaum, supra note 27, at 788-814 (describing how the competition between leagues has changed). 
petition in this regard. ${ }^{187}$ Moreover, other entertainment industries, such as film and television, compete with professional sports for the consumer dollar.

Although the preceding discussion indicates that the NFL inay endure strong competition froin other professional and college sports, the small number of scheduled games in the NFL adds to its competitiveness. The NFL plays just sixteen games per season; the NBA and MLB play eighty-two and 162 games, respectively. People are less prone to look for substitutes when only a sinall number of games are playedeach game is attractive to the spectator. Nevertheless, the NFL appears to face some outside competition. This Note does not attempt to determine the elasticity of deinand for each sport; rather, the point is that elasticity of demand is calculable and that it varies among the three sports. As noted above, courts inust analyze the competition among sports leagues and other modes of entertainment to apply accurately the antitrust laws.

\section{The Dynamic Nature of the Sports Industry}

Courts must realize that the competitive effeets of free agency restrictions are a function of the particular market's structure. ${ }^{188}$ Furthermore, because sports markets are dynamic, not static, the questions in a Section 1 analysis nnay be answered differently if a change in the market's structure occurs.

For example, network broadcasting payments, spht equally among the teams, account for the bulk of NFL revenues; by contrast, basketball and baseball rely on local broadcasting and attendance, and involve hittle or no sharing among the teams. ${ }^{189}$ If the NFL opened regular season games to local broadcasting, resnlting in lower network contract revenues, the free agency restrictions would impair player mobility and salaries to an even greater extent. This would occur because local broadcasting revenues are more sensitive to a team's winning percentage than are those of network broadcasting, and thus player impact on revenues would increase with greater local broadcasting. For the same reasons, however, the free agency restrictions will have different consequences in terms of the NFL as a product and on consuiner wel-

187. College football bowl games and the NCAA basketball tournament have become extremely popular, but college baseball has not really caught on at the national level. One may argue that the NFL does not compete against college football because they play games on different days of the week; lowever, believe it or not, people may be able to consume only a limited supply of football per week.

188. See supra notes $135-43$ and accompanying text (description of market structure).

189. See supra text accompanying notes $137-40$. 
fare. A decision to abandon attendance revenue sharing in the NFL also would produce the same result as above. Individual team performance would affect attendance revenues to a greater extent, with the result that an individual would have a more significant impact on team revenues. ${ }^{190}$ Similarly, the analysis for MLB or the NBA changes with shifts in sharing schemes and the relative importance of revenue sources. ${ }^{191}$ Courts must consider the differences in league revenue structures because free agency restrictions will affect the labor market, the product market, and consumer welfare differently, depending on the structure of the particular league.

\section{ANalysis of the Free Agency Restrictions in POWELL V. NFL}

This Note has discussed both the specific factors that courts should consider in determining whether free agency restrictions violate Section 1 of the Sherman Act, and the likely impact such restrictions may have on those factors. That discussion provides the background necessary to evaluate the merits of the NFLPA's Section 1 claim against the NFL in Powell. The restrictions under scrutiny are the league's compensation scheme, the right of first refusal, and Plan B, which simply limits the compensation scheme to certain players. ${ }^{192}$

\section{A. Background of Powell v. NFL}

As discussed earher, the Eighth Circuit's latest ruling in Powell $v$. $N F L,{ }^{193}$ and the Supreme Court's recent denial of the player's petition for certiorari, ${ }^{194}$ indicate that the court will not reach the antitrust nierits of the NFLPA's claim in Powell. This result occurs because, to the extent that the court beheves that the NFL owners and players have previously agreed to free agency restrictions, the labor exentption immunizes those restrictions from the antitrust laws. ${ }^{195}$ The labor exeniption attenipts to harmonize the Sherman Act, which seeks to preclude anticonipetitive behavior, with the federal labor statutes, which favor collective

190. For example, according to the model, an additional victory would be worth $\$ 21,461$ more if the NFL shifted from the $60-40$ split to a no-sharing scheme.

191. If baseball's revenue sharing proposal, see supra note 60 , goes into effect, the analysis will shift accordingly. The trend to increased cable contacts, though not accounted for in the model, also will alter the analysis. Increased cable coverage will affect network contracts.

192. See supra notes $37-59$ and accompanying text (description of the restrictions).

193. 888 F.2d 559 (8th Cir. 1989).

194. Powell v. NFL, 111 S. Ct. 711 (1991).

195. See supra note 14 and accompanying text. 
bargaining between unions and employers. ${ }^{196}$ The NFLPA and the NFL owners agreed on the free agency restrictions in their 1982 collective bargaining agrecinent, which had expired at the time of the suit. The owners and players reached an impasse in their negotiations over a new collective bargaining agreement; ${ }^{197}$ thus, the issue presented to the Eighth Circuit was whether an impasse terminates the labor exemption. ${ }^{198}$ The Eighth Circuit, in reversing the District Court, ruled that the labor exemption "protects agrcements conceived in an ongoing relationship" and does not terminate when the sides reach an impasse. ${ }^{199}$

The issue of whether an impasse should terminate the labor exemption has been hotly debated. In a recent article, Professor Lock provides strong policy reasons why an impasse in negotiations should make the labor antitrust exemption mapplicable. ${ }^{200}$ Lock argues that allowing the owners to use the labor exemption to shield anticompetitive conduct after the expiration of the agrecinent permits the League to coinpletely circunivent the antitrust laws. ${ }^{201}$ Moreover, it is irrelevant that the players previously agreed to the restrictions because the union no longer wants those restrictions. ${ }^{202}$

196. Comment, Sport in Court: The Legality of Professional Football's System of Reserve and Compensation, 28 UCLA L. REv. 252, 268 (1980). For cases dealing with the non-statutory labor exemption, see Smith v. Pro Football Inc., 420 F. Snpp. 738, $741-44$ (D.D.C. 1976), rev'd in part, 593 F.2d 1173 (D.C. Cir. 1978); Robertson v. NBA, 389 F. Supp. 867, 884-90 (S.D.N.Y. 1975); Philadelphia World Hockey Club, Inc. v. Philadelphia Hockey Club, Inc., 351 F. Snpp. 462, 496-500 (E.D. Pa. 1972). For the non-sport court decisions, see Local 189, Amalgamated Meat Cutters v. Jewel Tea Co., 381 U.S. 676, 691 (1965); United Mine Workers v. Pennington, 381 U.S. 657 (1965); Allen Bradley Co. v. Local 3, IBEW, 325 U.S. 797 (1945); United States v. Hutcheson, 312 U.S. 219, 232 (1941). Substantial commentary has been generated regarding the labor antitrust exemption and sports. See Lock, supra note 15 (critiquing Powell and proposing modification of the free agency system to give more weight to player interests); Lock, supra note 183 (proposing alternative analysis of the labor exemption which would recognize the bargaining history between the parties as the urique nature of sports); Roberts, Sports League Restraints on the Labor Market: The Failure of Stare Decisis, 47 U. PITT. L. REV. 337 (1986) (arguing that sports league cases involving labor market impacts fail to provide guidance on how antitrust law should be applied properly); Roman, supra note 9 (arguing that Powell was decided correctly and asserting that players have been hurt by union's resort to the courts).

197. Powell v. NFL, 678 F. Supp. 777 (D. Minn. 1988).

198. Powell v. NFL, 888 F.2d 559 (8th Cir. 1989).

199. Id. at 569.

200. Lock, supra note 183.

201. Lock argues for several reforms in addition to terminating the antitrust exemption when the agreement expires. First, the substantive provisions of the NLRA should be amended to accommodate the urique nature of sports; second, courts should annunciate the types of free agency restrictions that will satisfy the Rule of Reason standard; and third, in exchange for the preservation of the antitrust exemption, Congress should require the NFL to provide economic incentives for teams to win on the playing field; specifically, the NFL should modify the pooling of television revenues. Id. at $405-07$.

202. Id. at 376. 
In contrast, Professor Roman argues that the latest ruhing is sound. ${ }^{203}$ Roman stresses that the labor exemption should apply because the NFLPA is trying to use the courts and antitrust laws to achieve a result that it cannot attain through bargaining. ${ }^{204}$

Despite the latest ruling, several factors indicate that the NFL free agency restrictions will be scrutinized under the antitrust laws. At least three possible ways exist in which the NFL free agency restrictions may become subject to antitrust scrutiny. ${ }^{205}$ First, the players could complete the decertification of the NFLPA and an individual player could bring suit against the NFL. 206 Second, the court could rule in McNeil $v$. $N F L{ }^{207}$ that the labor exemption does not immunize the unilaterallyimposed free agency restrictions (Plan B) from antitrust scrutiny. ${ }^{208} \mathrm{Fi}$ nally, at some later point in negotiations, the court could determine that the 1982 restrictions are no longer "conceived in an ongoing relationship" and subject them to antitrust scrutiny. ${ }^{209}$ It is possible, of course, that the sides will reach an agreeinent before any of these possibilities arise.

If the Powell or another court reaches the antitrust inerits of the players' case, it should separately analyze each free agency restraint's competitive effect on the players, the NFL as a product, and consumer welfare. The court should be conscious of the two principal findings of this Note: First, that free agency restrictions that inhibit teams froin signing free agents for artificially high prices are reasonable and procompetitive on the product side, and they also improve consumer welfare, and second, that courts have exaggerated the anticoinpetitive effects of free agency restrictions on the labor market-the long term effect of these restrictions on player mobility and salaries is not great.

\section{B. Economic Evaluation of the Free Agency Restrictions Attacked in Powell v. NFL}

1. Compensation Scheme. The system of requiring pre-determined compensation for lost free agents, whether for all or just some players, imposes an added cost to signing a free agent. This restriction inhibits teams from signing free agents for artificially high prices.

203. Roman, supra note 9 , at 114 .

204. Id.

205. See supra notes $17-23$ and accompanying text.

206. See supra notes 17-18 and accompanying text; see also Roman, supra note 9, at 124 .

207. Civ. No. 90-14-02-JNB (D.N.J. April 10, 1990).

208. See supra notes 19-21 and accompanying text.

209. See supra notes $22-23$ and accompanying text. 
The compensation system is extremely procompetitive in terms of consumer welfare. The restriction prevents the artificially inflated shortterm costs caused by owner irrationality, and the resultimg transfer of these costs by the owners to consumers.

To some extent, the compensation requirement also benefits the NFL as a product. Preventing higher short-term costs from being passed on through higher ticket and broadcasting prices, and decrcased stadium quality, makes the NFL more competitive with other forms of entertainment. The improvement in competitiveness of the NFL product depends on its cross-elasticity of demand with other entertainment products. By preventing irrational short-term player movement, the restriction also enhances spectator interest and NFL competitiveness by maintaining continuity among teams and appealing to fan loyalty to players. The large number of Plan B free agents who have switched teams demonstrates that player movement will occur without free agency restrictions.

On the other hand, the compensation scheme does not improve NFL product competitiveness by enhancing intraleague competition. MLB, which has greater player movement with a less restrictive free agency system than the NFL, due to the greater financial impact of an individual player in baseball than in football, has not experienced a decline in intraleague competition under its lenient free agency system. Therefore, the compensation scheme will not improve NFL, intraleague competition.

With regard to the labor market, the compensation requireinent has slight anticompetitive effects on the players. The restraint decreases player mobility that would otherwise occur in the short run due to irrationality. However, in the absence of restrictions, in the long run owners would recognize that players do not generate additional revenues and would stop signing free agents. As a result, the decrease im player mobility caused by the compensation system would eventually decline. The compensation system also reduces player salaries in the short run because the restriction curtails much of the owners' irrational bidding for players. However, for the same reasons that the decrease in player mobility falls off in the long run, the decrease in player salaries otherwise attainable without the restriction will decrease in the long run. In fact, the possible decrease in competitiveness of the NFL as a product if the compensation scheme were removed (due to the passing on of higher salary costs to consumers) may cause the salary decrease caused by the restriction to be even less than originally expected.

The court must weigh all of these factors together. An objective balancing of all factors indicates that the compensation scheme is procompetitive in net, and, therefore reasonable. 
2. Right of First Refusal. The right of first refusal allows a free agent's team to match any other team's offer and thereby retain the free agent. Unlike the compensation scheme, this restriction fails to inhibit teams from signing free agents for artificially high salaries-the main criteria necessary for a restriction to be procompetitive on the product side and on consumer welfare. A player may not necessarily switch teams due to the right of first refusal; however, he will receive the higher salary offered by the irrational owner, either from the new or the current team. Therefore, the restriction fails to achieve any of the procompetitive benefits of preventing short-term owner irrationality.

The right of first refusal produces a mild procompetitive effect on the NFL as a product. The current team is more likely to retain the free agent, which promotes team continuity and fan loyalty to players. Continuity and fan loyalty should increase spectator interest in football and increase NFL competitiveness. However, the restriction does not increase NFL competitiveness by either significantly improving intraleague balance or by preventing clubs from passing on to the consumers the short term artificial costs through higher prices.

The right of first refusal has a shight anticompetitive effect on the players. Players do not suffer lower salaries because they still receive the highest salary offer. However, the restraint decreases player mobility in the short run. Without the right, player inovement would be great in the short run because of owner irrationality. The right of first refusal reduces this mobility to the extent that the original owner also acts irrationally by matching the offer. If the original owner matches the offer, the player cannot change teams. However, this decrease in mobility caused by the right of first refusal would fall off in the long run as owners realized that the players' increased salaries were not being matched by increased revenues.

The cumulative competitive effect of the right of first refusal is very close, as the right produces only marginal effects throughout. However, a rule that produces no significant gains is uimecessary and thus unreasonable.

In summary, the court should rule that the coinpensation systein is a reasonable restraint and not a Section 1 violation. The right of first refusal is of marginal benefit at most and, if looked at in isolation, is unnecessary. Thus, the court shonld find it unreasonable. If the court wishes to consider the restrictions as a package and not in isolation, however, the restraints imposed by the NFL do not violate Section 1 as an unreasonable restraint on trade. The restrictions as a whole are not unreasonable because their cumulative effect is procoinpetitive. 


\section{ConClusion}

The NFLPA has brought suit against the NFL owners claiming that the League's restrictions on free agents, including a compensation scheme and the right of first refusal, are unreasonable restraints of trade and violate Section 1 of the Sherman Act. Prior cases dealing with free agency restrictions indicate that courts consider only the effect a free agency restriction has on the players (the labor market). However, a complete Section 1 analysis of any free agency restraint must include the restraint's impact on the NFL as a product and on consumer welfare in general.

Moreover, in evaluating the effect that a free agency restriction has on a particular factor, courts frequently make improper econoimic assumptions about the workings of sports markets. Therefore, their assessments of how a free agency restraint affects competition are often incorrect. The statistical model used herem deinonstrates that players can significantly affect team revenues in the NBA and MLB, but not in the NFL. The distinction ainong the three sports occurs largely because of the different economic structure of each league. The inodel allows one to assess the effect of a free agency restriction on the three factors relevant for Section 1 purposes: the labor market, the NFL as a product, and consumer welfare. Moreover, the inodel strikingly demonstrates that identical free agency restrictions in the three sports produce different effects on these three factors. Courts must recognize these effects and also be aware that the structure of each league is subject to change, a factor that can significantly alter a Section 1 analysis.

Applying this analysis to the free agency restrictions under attack in Powell, the NFL's restrictions as a whole are reasonable restraints and do not violate Section 1 . The compensation system has procompetitive justifications in regards to the NFL product and the general consumer, whereas the anticompetitive effects on the players are minor. The coinpensation scheme is procompetitive in net, and is therefore reasonable. The right of first refusal, on the other hand, has relatively imsignificant procompetitive justifications on the product market or on consumer welfare, while having a somewhat anticompetitive effect on the labor market. Taken in isolation, the right of first refusal may be unreasonable; when considered with the compensation scheme, however, the total is procompetitive and reasonable. It must be further emphasized that although these restrictions are reasonable in the NFL, they are not necessarily reasonable for other sports. 
